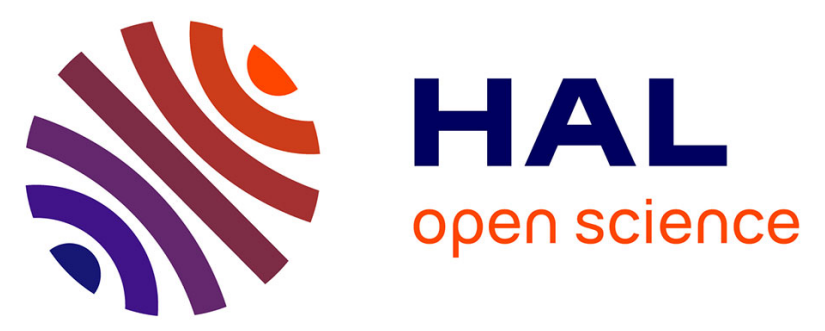

\title{
Multiproxy analyses of Lake Allos reveal synchronicity and divergence in geosystem dynamics during the Lateglacial/Holocene in the Alps
}

Rosine Cartier, Elodie Brisset, Frédéric Guiter, Florence Sylvestre, Tachikawa Kazuyo, Edward J. Anthony, Christine Paillès, Helene Bruneton, Edouard Bard, Cecile Miramont

\section{To cite this version:}

Rosine Cartier, Elodie Brisset, Frédéric Guiter, Florence Sylvestre, Tachikawa Kazuyo, et al.. Multiproxy analyses of Lake Allos reveal synchronicity and divergence in geosystem dynamics during the Lateglacial/Holocene in the Alps. Quaternary Science Reviews, 2018, 186, pp.60-77. 10.1016/j.quascirev.2018.02.016 . hal-01795351

\section{HAL Id: hal-01795351 \\ https://hal.science/hal-01795351}

Submitted on 1 Apr 2019

HAL is a multi-disciplinary open access archive for the deposit and dissemination of scientific research documents, whether they are published or not. The documents may come from teaching and research institutions in France or abroad, or from public or private research centers.
L'archive ouverte pluridisciplinaire HAL, est destinée au dépôt et à la diffusion de documents scientifiques de niveau recherche, publiés ou non, émanant des établissements d'enseignement et de recherche français ou étrangers, des laboratoires publics ou privés. 


\title{
Multiproxy analyses of Lake Allos reveal synchronicity and divergence in geosystem dynamics during the Lateglacial/Holocene in the Alps
}

\author{
Rosine Cartier ${ }^{\text {a, b, }{ }^{*}, 1}$, Elodie Brisset ${ }^{\text {a, b, }}{ }^{* *}, 1$, Frédéric Guiter ${ }^{\mathrm{b}}$, Florence Sylvestre ${ }^{\mathrm{a}}$, \\ Kazuyo Tachikawa ${ }^{a}$, Edward J. Anthony ${ }^{a}$, Christine Paillès ${ }^{a}$, Hélène Bruneton ${ }^{a}$, \\ Edouard Bard ${ }^{a}$, Cécile Miramont ${ }^{\mathrm{b}}$ \\ a Aix Marseille Univ, CNRS, IRD, Coll France, CEREGE (Centre Européen de Recherche et d'Enseignement des Géosciences de l'Environnement), Aix-en- \\ Provence, France \\ b Aix Marseille Univ, Univ Avignon, CNRS, IRD, UMR 7263 IMBE (Institut Méditerranéen de Biodiversité et d'Ecologie Marine et Continentale), Marseille, Aix- \\ en-Provence, France
}

\begin{abstract}
A B S T R A C T
Palaeoenvironmental reconstructions of ecosystem responses to external forcing are generally limited by the difficulty of understanding the geosystem as a whole, because of the complex interactions between ecological compartments. Therefore, identifying which geosystem compartments or proxies co-vary is a prerequisite in unravelling the propagation of disturbances (e.g. climatic or anthropogenic) from one compartment to another. A multiproxy study of a continuous 13,500 -year sedimentary profile cored in Lake Allos (European Alps, $2200 \mathrm{~m}$ a.s.l) was carried out on the basis of high-resolution sedimentological, geochemical, and botanical analyses, as well as determination of aquatic biotic proxies (diatoms, ostracods). These multiproxy datasets are rare at these high altitudes. Major changes occurred in the course of the palaeoenvironmental history of this alpine watershed at 12,000, 8600, 7200 and $3000 \mathrm{cal}$. BP. During the Holocene, two main transitions were recorded in all the ecological compartments (8600 and 3000 cal. BP), but the period 4500-3000 cal. BP stands out because of major changes that concerned only the lacustrine ecosystem. The frequent switches in lake level might correspond to the $4.2 \mathrm{ka}$ climatic event. Proximity of this alpine lake to climatically-sensitive thresholds (ice-cover, thermal stratification, hydrological balance) may have amplified climatic signals in the lake ecosystem. This study illustrates the difficulties inherent to the use of common intra-Holocene stratigraphical limits, given that ecological compartments are likely to have different responses to forcing factors depending on the characteristics of the watershed and its capacity to accommodate disturbances.
\end{abstract}

\section{Introduction}

Alpine ecosystems, located above the upper limit of forest growth, are particularly influenced by cold temperatures and duration of the snow-free period (Körner, 1995). Increase in temperatures and changes in precipitation regime, expected in the European Alps throughout the 21st century (Gobiet et al., 2014),

\footnotetext{
* Corresponding author. Department of Geology, Lund University, Sölvegatan 12, 22362 Lund, Sweden.

** Corresponding author. IPHES, Campus Sescelades URV, Edificio W3, Zona Educacional, 4, 43007 Tarragona, Spain.

E-mail addresses: cartier.rosine@gmail.com (R. Cartier), elodie.brisset@gmail. com (E. Brisset).

1 These authors contributed equally to this work.
}

may expose mountain landscapes to profound and unprecedented modifications. These modifications might include upward movement of the treeline (Harsh et al., 2009), extinction of plant communities (Cannone et al., 2007), and pronounced soil drought (Heinrich and Gobiet, 2012). Climate change is also likely to affect natural lake physical and biological properties (Wolfe et al., 2003; Parker et al., 2008; Rühland et al., 2008; Perga et al., 2015), with severe consequences on lacustrine ecosystem services (e.g., water quality, leisure activities). On the other hand, local drivers of environmental change such as land use (pastoral activities), soil development, and geomorphic processes (e.g., erosion) will continue to play a major role in the trajectories of alpine ecosystems in a complex interaction with climate (Bennion et al., 2011; Macias-Fauria and Johnson, 2013). In addition, most systems are 
not in a steady state, and are characterised by natural variability and species succession (Hilderbrand et al., 2005). Disentangling the factors that control ecosystem functioning is a prerequisite for a better understanding of climate- or human-related environmental changes (Birks and Birks, 2006). Differences in temporal behaviour can be used to distinguish long-term autogenic successional trends from higher-frequency fluctuations that are driven mainly by external forcing (Adrian et al., 2009). Thus, improving knowledge on alpine ecosystem functioning requires a global understanding of how the diverse compartments of the environment (i.e., both biotic and abiotic, and terrestrial and aquatic) respond to perturbations at a multi-millennial timescale.

Multiproxy datasets on lacustrine and terrestrial ecosystems covering the Lateglacial-Holocene period are rare at these high altitudes, even in the relatively well-studied mountains of Europe. Noteworthy examples of multiproxy studies have been carried out in Lakes Basa de la Mora and Enol in the Pyrenees (respectively by Pérez-Sanz et al., 2013, and Moreno et al., 2011), and in Lakes Brazi and Gales in the Carpathians (Tóth et al., 2017). Regarding the Alps, multiproxy studies have been carried out in Sägistalsee (Lotter and Birks, 2003) and Bachalpsee (Lotter et al., 2006) in the Swiss Alps, and in the Oberer Landschitzsee in Austria (Schmidt et al., 2006). In the central Alps, the impact of ancient anthropogenic pressure in generating mountain vegetation changes has been demonstrated. The concomitance of the first expansion of alder trees and replacement of fir by spruce forests, the increase of ruderal plants associated with pastoral farming, and that of anthropogenic fires aimed at creating open landscapes during the Late Neolithic (59005200 cal. BP), show clearly that vegetation changes during this period did not result from climate change, but were determined by land use (Gobet et al., 2003; Tinner et al., 2005). In the same vein, looking for synchronicity between anthropogenic-driven proxies and other proxies is a good way of identifying this human influence on local geosystem changes. Various methods have proved their efficiency in this regard, including tracking nutrient-rich plants using pollen (Rey et al., 2013) and sediment DNA (Pansu et al., 2015), and that of the presence of animals through coprophilous fungi (Schwörer et al., 2014), coprophilous coleopterans (Ponel et al., 2011), and sediment DNA (Giguet-Covex et al., 2014). For periods prior to anthropogenically-induced vegetation changes, it is also frequent having aquatic biota changes that follow catchment dynamic in the Alps, especially as regards vegetation succession. For example, whilst climate-induced lake-level changes during the Mid-Holocene may have been a cause of chironomid succession in the Sägistalsee (Heiri and Lotter, 2003), a concomitant upward migration of spruce resulting in denser woodlands in the lake's catchment ( $6500 \mathrm{cal}$. BP) may also have caused this trend. The close link between lake biota and terrestrial dynamics is just as strong in the Late Holocene during which large nutrient loadings due to soil erosion and pasturing resulted in anoxia of bottom lake waters (Heiri and Lotter, 2003). Finally, when investigating all geosystem compartments through large multiproxy datasets, the role of climate changes may be still unclear. At the Sägistalsee (Lotter and Birks, 2003), for instance, where independent climate proxies (e.g. solar insolation and North Atlantic cold events) have been confronted statistically with all the environmental proxies, no significant results have been found. Conversely, when vegetation change is proposed as an explanatory variable, all commonly employed datasets (i.e. cladoceran, chironomids, grain-size, elemental geochemistry, magnetic susceptibility) are statistically well-explained. Obviously, one cannot expect to strictly identify climate forcing based on a mono-proxy study during the Lateglacial-Holocene, whether or not there is a human impact, because of the 'cascade' response of geosystem compartments. This pattern is met in numerous partial multi-proxy studies of the Alps (e.g. Giguet-Covex et al., 2011; Bajard et al., 2017; Pini et al., 2017). Thus, an appropriate way of tracking climate oscillations is first to identify which geosystem compartments or proxies co-vary, in order to then proceed by elimination.

As a result of complex environmental responses during the Holocene, and the variability of the proxies studied, no formal subdivision of the Holocene exists in the Quaternary community, even though a tripartite subdivision including an "early", "mid", and "late" Holocene has been largely employed in research papers in the last few decades (Walker et al., 2012). The first attempts to propose a formal division of the Holocene were based on palynological stratigraphy but time lags in vegetation responses and a lack of robust age-depth models limited the use of this subdivision at the global scale (Mangerud et al., 1974). More recently, advances in geochronology and palaeoclimatic archives (e.g. dendrochronological series, ice core data) have led to the emergence of another tripartite division based on two climatic events at 8200 and 4200 cal. BP (Walker et al., 2012). However, the benefits of applying this scheme to the description of new Holocene records still need to be discussed, as these subdivisions might not be consistent with the main boundaries highlighted by environmental proxies.

In this context, the transition from the Mid-to the Late-Holocene period assumes particular significance since major environmental changes in the European Alps and Mediterranean regions have been highlighted in connection with large palaeohydrological events (Magny et al., 2013) and contemporaneously with increasing human impact (this period has been termed the "Mid-Holocene melange" (Roberts et al., 2011)). At the interface between these two geographic domains, the Mediterranean Alps have been particularly well-investigated, providing 14 continuous sedimentary records for this time period (Brisset et al., 2015 and references therein). All the study sites recorded major vegetation changes during this Mid-to Late-Holocene transition. However, with the exception of the records from Lake Long Inférieur (including pollen, insect and chironomid analyses; Ponel et al., 2001; Gandouin and Franquet, 2002), and Lake Vens (coupling sedimentology and pollen analysis; Brisset et al., 2015), all other records were exclusively based on pollen analysis (i.e. Beaulieu de, 1977; Dijkstra et al., 1990; Kharbouch, 2000; Finsinger, 2001). Moreover, age controls were also disparate between sediment cores (Brisset et al., 2015), and many of these records were solely constrained with palynostratigraphy (Beaulieu de, 1977).

The present study aims at reconstructing past alpine environment functioning and the driving forces in the Mediterranean Alps by characterizing, at a high resolution, palaeoenvironmental changes of the Allos geosystem (Fig. 1) during the Lateglacial and the Holocene. To achieve this goal, we use a compartment-oriented approach (i.e., to access the main environmental components within the same sediment archive) that includes geomorphic processes (derived from sedimentology and geochemistry), vegetation changes (pollen), characterization of the lacustrine environment (diatoms, ostracods, geochemistry), together with a wellconstrained chronostratigraphy (radiocarbon dates). This approach will enable identification of synchronicity and divergence between proxies and geosystem compartments particularly during the Mid- and Late-Holocene periods, deciphering of the processes involved, and determination of the types and timing of environmental responses. Finally, the common environmental boundaries between proxies will be confronted with the traditional tripartite subdivision of the Holocene. 

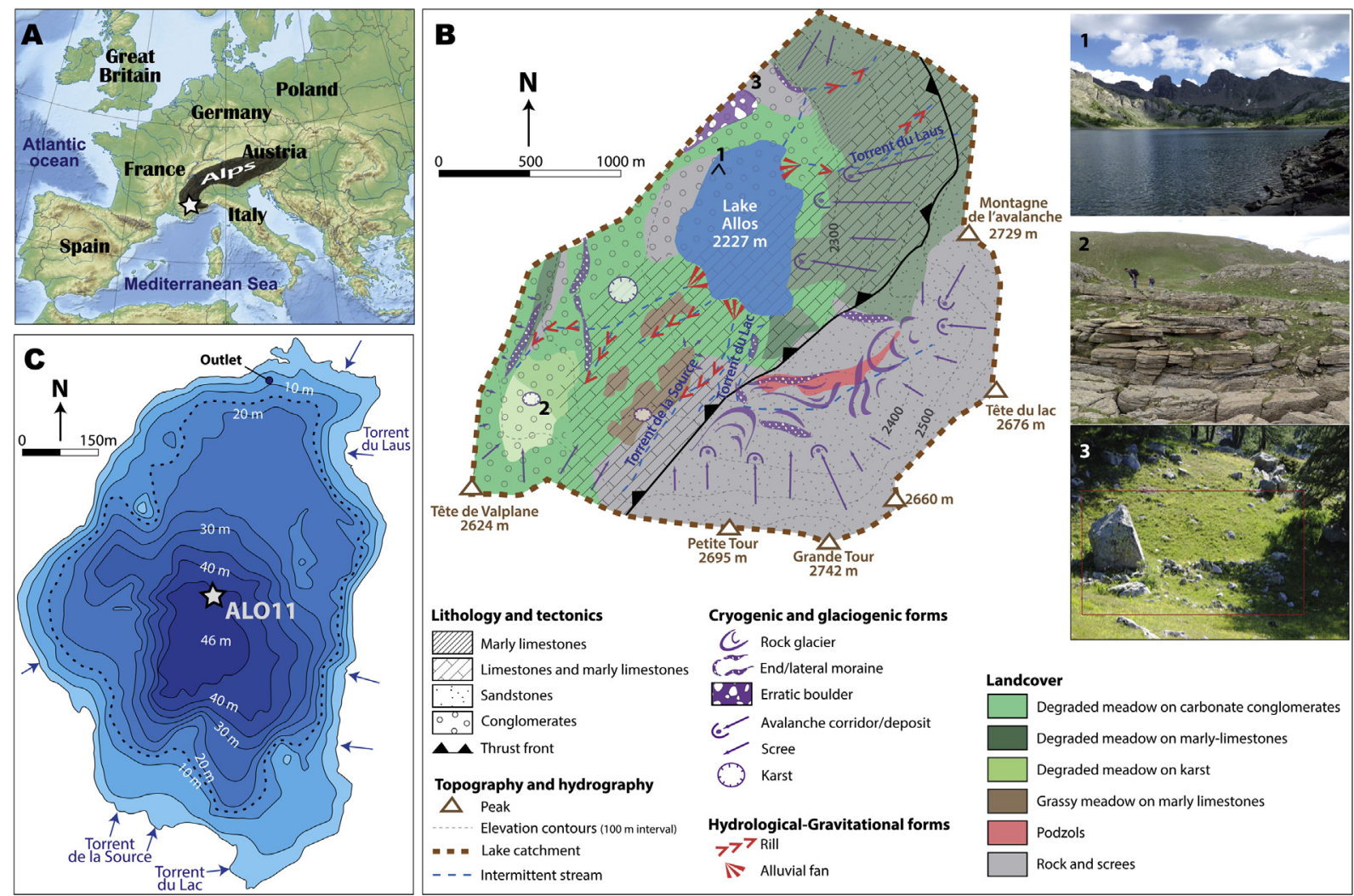

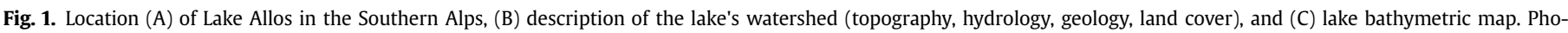
tographs illustrate (1) a general overview of the landscape, (2) karst landforms, (3) stone structure enclosing a morainic boulder and with presence of flint.

\section{Materials and methods}

\subsection{Setting}

Lake Allos $\left(44^{\circ} 14^{\prime} \mathrm{N}, 6^{\circ} 42^{\prime} 35^{\prime \prime} \mathrm{E}\right.$, Fig. 1$)$ is located $2227 \mathrm{~m}$ a.s.l. in the south-western Alps (Mercantour National Park). Lake Allos is the largest natural high-altitude lake (1 km-long, $700 \mathrm{~m}$-wide, $5 \mathrm{~km}^{2}$ ) in the alpine range (Fig. $1 \mathrm{~B}$ and ). The setting is marked by a seasonally contrasting Mediterranean climate that is influenced by elevation differences. Mean annual precipitation is $1152 \mathrm{~mm}$, occurring both as snow and rainfall, mainly in winter and spring (period 1951-1965 AD). Intense rainfalls occur essentially in late summer and autumn (Douguedroit, 1976; Buzzi and Foschini, 2000; Boudevillan et al., 2009). The catchment is covered by snow for about 8 months a year, and the lake is frozen from November/ December to May/June. Lake water comes from snow melt and rainfalls feeding intermittent torrents (Fig. 1). The lake has no surface outlet. Water losses are due to evaporation and an underground outlet. The lake's outlet feeds the Torrent of Chadoulin, the flow of which sometimes ceases during dry summers. The interannual lake water-level variation can attain $13 \mathrm{~m}$ (Agence de l'eau Rhône Méditerranée Corse, 2013, unpub. rep.).

The lake is situated in a deep glacio-karstic depression dominated by relatively steep slopes and mountain crests rising to $2780 \mathrm{~m}$, and consists of two sub-basins determined by lithology (Wilhelm et al., 2012; Brisset et al., 2014a,b): one sub-basin forms a shallow platform (20 m-deep) to the north, and consists of erodible rocks, limestone, blue marls and conglomerates (Figs. 1B and 2), partly covered by fine-grained glacial deposits. The other sub-basin is a deep feature $(42 \mathrm{~m}$ ) to the south (Fig. 1C) dominated by less erodible sandstones of the autochthonous subalpine domain (Jorda,
1975). The area was affected by past glaciations and the latest glaciers have deposited two terminal moraines, lateral moraine ridges, and erratic boulders (Brisset et al., 2014a,b). The bed of the Source stream (Torrent de la Source, Fig. 1B) is strewn with large glacial boulders of sandstone. The region is drained by intermittent torrents that debouch in the lake through well-developed fan deltas.

Lake Allos is characterised by poorly mineralised oligotrophic to mesotrophic freshwater. Water physico-chemical properties were analysed from June to September 2013 (Agence de l'eau Rhône Méditerranée Corse, 2013, unpub. rep.). The results showed that water temperatures ranged from 8 to $15^{\circ} \mathrm{C}$ in the epilimnion ( $<15 \mathrm{~m}$ depth), but were constant at $4{ }^{\circ} \mathrm{C}$ in the hypolimnion. Water $\mathrm{pH}$ was neutral to alkaline (7-8.8), with low conductivity (137-184 $\left.\mu \mathrm{S} . \mathrm{cm}^{-1}\right)$, and high oxygen saturation (100\%) up to the $10 \mathrm{~m}$-depth. Short periods of deoxygenation of deep waters occurred in late summer. Lake-water diatom flora identified in 2007 and 2013 are dominated by planktonic diatoms (Agence de l'eau Rhône Méditerranée Corse, 2013). During final ice-cover melt, in June, the dominant species are Cyclotella cyclopuncta and Fragilaria ulna var. angustissima, and during summer (July to September) assemblages are characterised by $C$. cyclopuncta and F. ulva var. acus.

The catchment is covered by alpine meadow (29\%) on the smooth northern and western slopes, whereas the steep southern and eastern slopes are characterised by bare terrain (bedrock, scree, representing $70 \%$ of the area). A young forest of Larix decidua covers conglomerates and moraine ridges in the north. Isolated trees occur sparsely at elevations above $2250 \mathrm{~m}$. Lake Allos catchment presents evidence of past human frequentation, including flints and stone enclosures (Figs. 1B and 3). Archaeological excavations are needed 

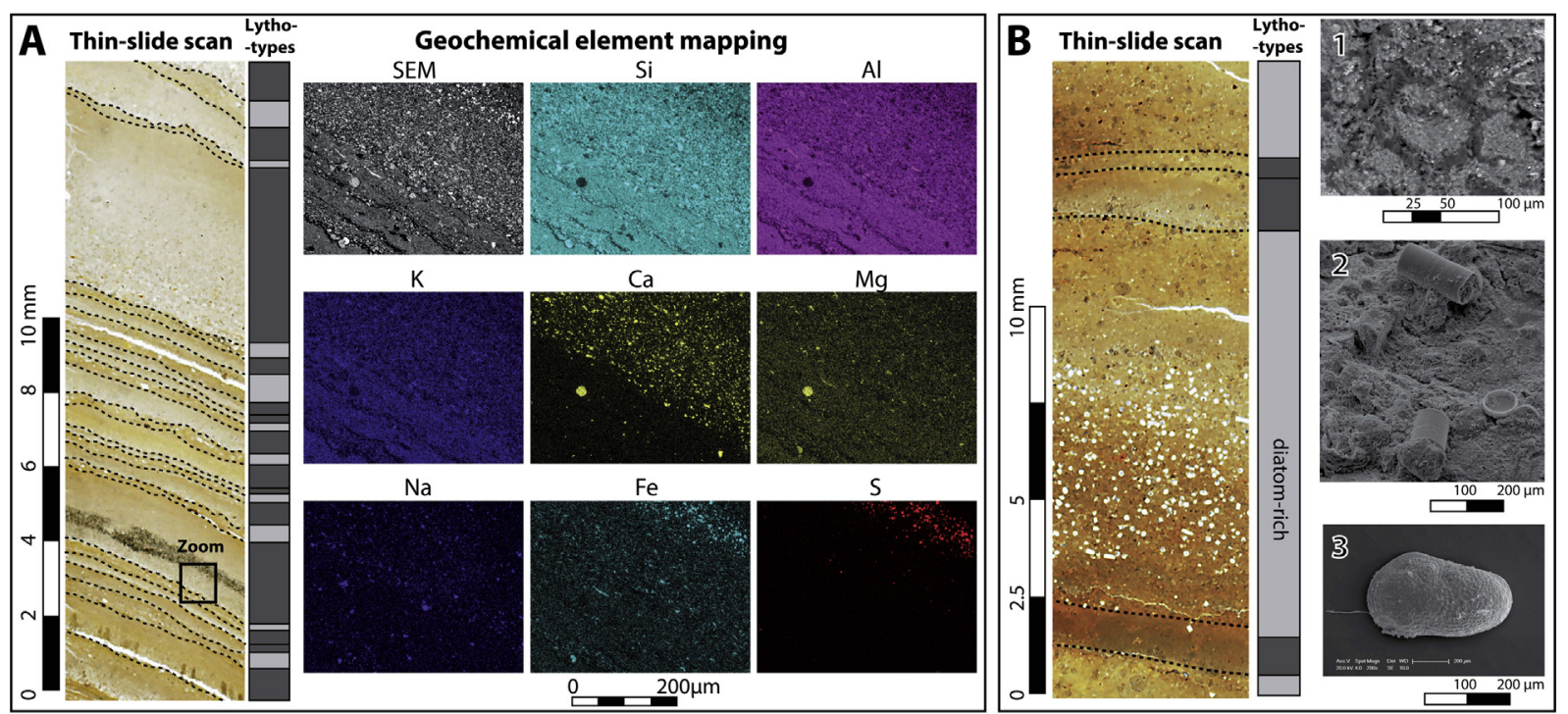

Fig. 2. (A) Microscopic images of minerogenic laminations and synthetic lithology (light grey: clay with isolated clasts (dropstone layer), dark grey: normally graded bed (flood layer). Enlarged natural light scan and SEM image of alternating flood layers and dropstone layers. Elemental-Dispersive Spectrometer mapping of silica ( $\mathrm{Si}$ ), aluminium (Al), potassium $(\mathrm{K})$, calcium $(\mathrm{Ca})$, magnesium $(\mathrm{Mg})$, sodium $(\mathrm{Na})$, iron $(\mathrm{Fe})$ and sulphur $(\mathrm{S})$. Increasing colour intensity is related to higher element concentrations. (B) Thin-section image of organic-rich interval and synthetic lithology (light grey: organic layer, dark grey: flood layer). (B1) SEM image of organic-rich bed with bioturbation figures. Regions of high porosity appear in dark grey due to carbon-rich resin and abundance of carbon in organic matter. (B2) Colonies of the diatom Ellerbeckia arenaria. (B3) Valve of the ostracod Cytherissa lacustris. (For interpretation of the references to colour in this figure legend, the reader is referred to the Web version of this article.)

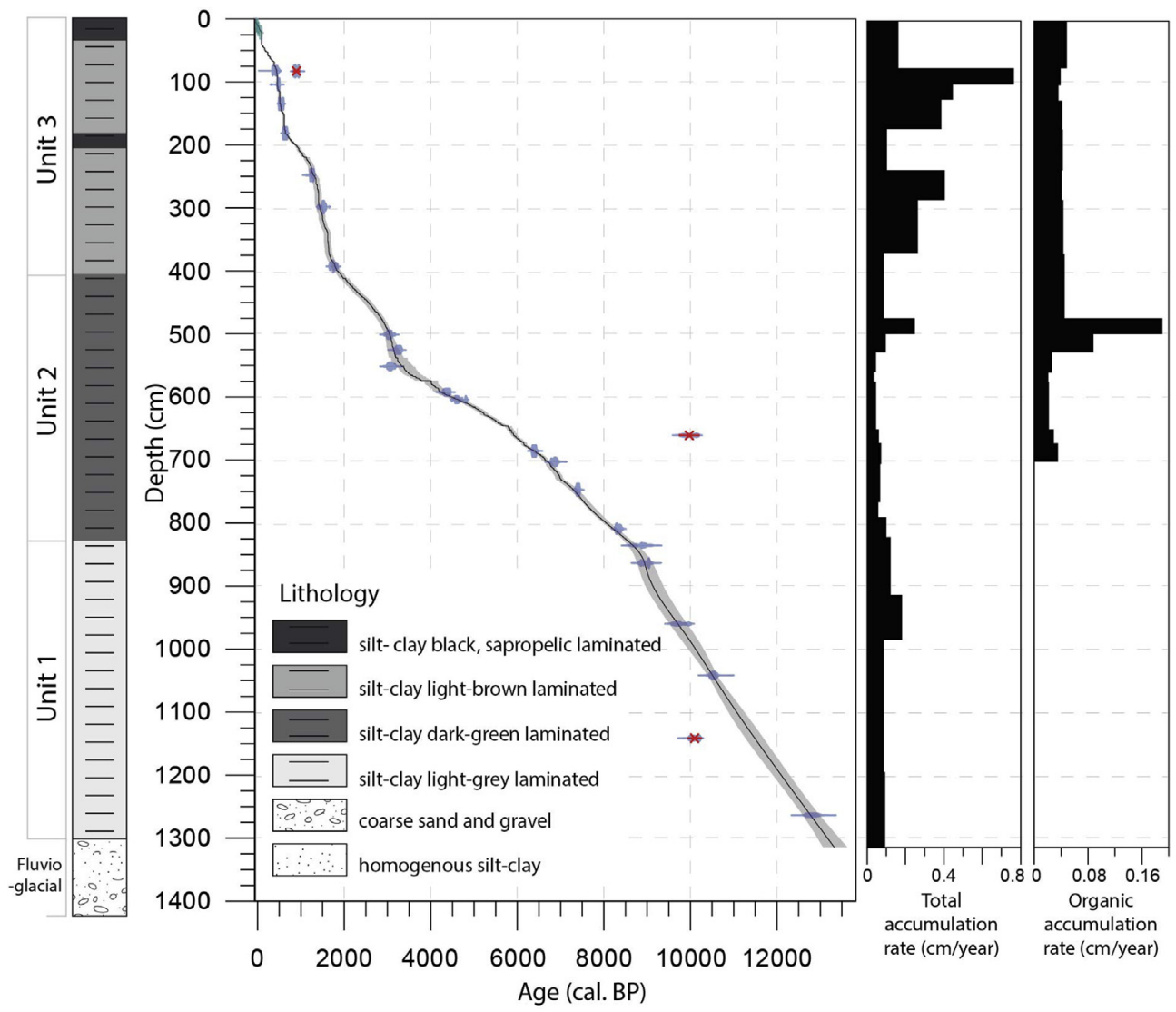

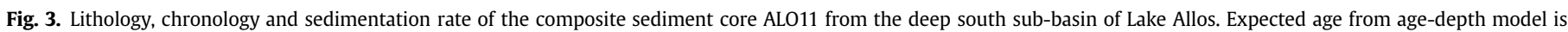
indicated by the bold line and the $95 \%$ confidence interval by the grey envelope. ${ }^{14} \mathrm{C}$ dates with crosses were excluded before model calculation. 
to investigate the timing and functioning of this human occupation. Based on the well-studied valleys of the Southern Alps (Walsh and Mocci, 2016), these structures are probably prehistoric.

\subsection{Sediment coring and composite profile}

Seismic surveys have shown that the lake sediment infill is well stratified with no evidence of sediment reworking (Wilhelm et al., 2012). A long core was extracted from the deepest part of the lake (40 m-deep sub-basin) using a UWITEC piston-corer and floating platform (EDYTEM, Chrono-environment, France). The core location was selected in the deepest part of this sub-basin, which is characterised by the thickest lacustrine sediment column (Wilhelm et al., 2015). Four parallel holes a few metres apart $\left(44^{\circ} 14^{\prime} \mathrm{N}\right.$, $6^{\circ} 42^{\prime} 29^{\prime \prime} \mathrm{E}$; Fig. 1C) were cored to ensure complete section overlap (Supplementary Material 1). Three of the holes reached a decimetre-thick coarse sand unit overlying bedrock. The sediment deformation from $7.3 \mathrm{~m}$ to the core bottom is an artefact of the piston coring process. A short gravity core was also retrieved to preserve the sediment-water interface. Cores were split lengthwise, photographed at $10-\mathrm{cm}$ overlapping intervals, and described. All segments were correlated using distinct stratigraphic markers (typically graded layers) and layer counting (Supplementary Material 2). The continuous composite core ALO11 (14.11 m-long) was built from the best-preserved sections by bridging consecutive segments of one core with a segment of a parallel core (Supplementary Material 3).

\subsection{Age-depth model}

24 terrestrial macro-remains (wood bark, needles, twigs, insects, pieces of grass) were manually sampled from wet-sieved sediment at 200 and $100 \mu \mathrm{m}$-mesh sizes (Brisset et al., 2014a,b; Table 1) and subjected to ${ }^{14} \mathrm{C}$ AMS dating at the Poznan ${ }^{14} \mathrm{C}$ laboratory. The ALO11 cores were correlated with the ALO09P2 gravity cores to improve the chronology of the last millennia by bringing in 4 additional ${ }^{14} \mathrm{C}$ AMS ages from small-sized terrestrial debris (Etienne et al., 2013; Wilhelm et al., 2015). ${ }^{14} \mathrm{C}$ ages were calibrated at a \pm 2 sigma using IntCal13 (Reimer et al., 2013). The age-depth model has been calculated using the Clam R Package (Blaauw, 2010), taking into account the probability density functions of ${ }^{14} \mathrm{C}$ dates and sampled material. Previous analyses of thin sections from 0 to $7.3 \mathrm{~m}$ had enabled the identification of organic and detrital layers, corresponding respectively to continuous and instantaneous sediment accumulation (Brisset et al., 2017). Therefore, for this core interval we calculated the continuous accumulation rate by placing the organic layers end to end. From 7.3 to $13.1 \mathrm{~m}$, accurate measurements on the thin section are precluded by sediment deformation. Combining sedimentological analyses and the age-depth model computation allowed distinguishing the continuous organic accumulation rate from the total accumulation rate.

\subsection{Micro-remains and micro-facies analyses}

Wet sediment was sampled at selected depths for qualitative identification of sediment compounds. Sediments were watersieved at meshes of 100 and $200 \mu \mathrm{m}$ and observed under a binocular loupe coupled with a digital camera (Q-Imaging, IMBE laboratory). Thin sections were prepared at IMBE, EDYTEM, and in the MK factory by freeze-drying and embedding them under vacuum in epoxy resin (Brauer and Casanova, 2001). Microfacies observations were performed under a 2000x-1000x magnification optical microscope. Selected intervals were observed in a backscatter environment under the Scanning Electron Microscopy. The abundances of $\mathrm{Si}, \mathrm{Al}, \mathrm{K}, \mathrm{Ca}, \mathrm{Mg}, \mathrm{Na}, \mathrm{Fe}$, and $\mathrm{S}$ were mapped using Energy Dispersive X-ray spectroscopy on an Edax Genesis Apex 2 detector (Aix-Marseille University, France).

\subsection{Geochemical analyses}

Major element concentrations were measured on 66 samples ( $1 \mathrm{~cm}$-thick) selected from organic-rich layers or graded layers not thicker than $5 \mathrm{~mm}$. Prior to analysis, aliquots were heated at $1000^{\circ} \mathrm{C}$ for $7 \mathrm{~h}$ to obtain the loss-on-ignition weight. The relative concentrations of $\mathrm{SiO}_{2}, \mathrm{Al}_{2} \mathrm{O}_{3}, \mathrm{Fe}_{2} \mathrm{O}_{3}, \mathrm{MnO}, \mathrm{MgO}, \mathrm{CaO}, \mathrm{Na}_{2} \mathrm{O}, \mathrm{K}_{2} \mathrm{O}$, $\mathrm{TiO}_{2}$ and $\mathrm{P}_{2} \mathrm{O}_{5}$ were measured by mass spectrometry using an

Table 1

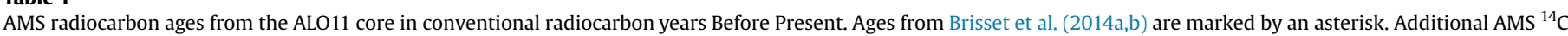
ages from core correlation with ALO09P2 are from Etienne et al. (2013) and Wilhelm et al. (2015). An additional age (Poz-63967) has been added in this study.

\begin{tabular}{|c|c|c|c|c|}
\hline ALO11 (cm in composite depth) & Material & Laboratory Code & Age uncal. BP & Calibrated years BP $(2 \sigma)$ \\
\hline 79 (ALO09P2) & Plant debris undiff & SacA 21325 & $315 \pm 30$ & $303-463$ \\
\hline 8.5 (ALOO9P2) & Plant debris undiff & SacA 21327 & $970 \pm 30$ & $796-933$ \\
\hline 106.5 (ALO09P2) & Plant debris undiff & SacA 21328 & $455 \pm 30$ & $480-536$ \\
\hline 131.5 (ALO09P2) & Plant debris undiff & SacA 21331 & $535 \pm 30$ & $512-631$ \\
\hline $181^{*}$ & Wood and needles undiff & Poz-50232 & $615 \pm 35$ & $547-657$ \\
\hline $250^{*}$ & Needles undiff & Poz-49766 & $1275 \pm 30$ & $1144-1287$ \\
\hline $300^{*}$ & Conifer bark uniff & Poz-49767 & $1645 \pm 30$ & $1418-1685$ \\
\hline $390^{*}$ & Plant debris undiff & Poz-49768 & $1795 \pm 30$ & $1625-1818$ \\
\hline $498.5^{*}$ & Twig of Salix sp. & Poz-46760 & $2880 \pm 35$ & $2885-3143$ \\
\hline $525^{*}$ & Twig of Larix/Picea & Poz-46759 & $3060 \pm 35$ & $3168-3364$ \\
\hline $556^{*}$ & Twig of deciduous tree & Poz-50223 & $2900 \pm 40$ & $2898-3205$ \\
\hline $589^{*}$ & Twig of deciduous tree & Poz-46758 & $3895 \pm 35$ & $4185-4422$ \\
\hline $605^{*}$ & Charcoal (gymnosperm) & Poz-50227 & $4090 \pm 35$ & $4445-4811$ \\
\hline $660^{*}$ & Twig of Salix sp. & Poz-50231 & $8840 \pm 50$ & $9706-10157$ \\
\hline $685^{*}$ & Twigs undiff & Poz-50224 & $5570 \pm 40$ & $6292-6435$ \\
\hline $708^{*}$ & Twigs of deciduous tree & Poz-50222 & $6040 \pm 40$ & $6786-6995$ \\
\hline $743^{*}$ & Plant debris undiff & Poz-50228 & $6660 \pm 40$ & $7462-7593$ \\
\hline $807^{*}$ & Twig of deciduous tree & Poz-50229 & $7670 \pm 50$ & $8386-8550$ \\
\hline $832^{*}$ & Bark of conifer and twig & Poz-50221 & $8090 \pm 80$ & $8720-9273$ \\
\hline $865.5^{*}$ & Twig of deciduous tree & Poz-46762 & $8050 \pm 50$ & $8725-9090$ \\
\hline $963^{*}$ & Twig undiff & Poz-50225 & $8820 \pm 50$ & 9689-10154 \\
\hline $1038^{*}$ & Plant debris & Poz-46757 & $9380 \pm 50$ & $10444-10732$ \\
\hline $1140^{*}$ & Plant debris undiff (0.4 mgC) & Poz-49768 & $8930 \pm 50$ & $9906-10210$ \\
\hline 1260 & Insect (thorax of Hymenoptera) & Poz-63967 & $11000 \pm 140$ & $12800-13070$ \\
\hline
\end{tabular}


inductively coupled plasma-atomic emission Thermo X7 spectrometer (ICP-AES) after $\mathrm{LiBO}_{2}$ alkaline fusion (Carignan et al., 2001) at SARM (France). Concentrations are expressed in oxide weight percentages (wgt \%) and uncertainty is $\pm 1 \%$. Total Carbon (TC), Total Nitrogen (TN), and Total Sulphur (TS) were measured on the same samples: $5 \mathrm{mg}$ of crushed sediment was placed in tin capsules prior to gas chromatography analysis with a FLASH 2000 series Thermo Fisher unit (IMBE, France). Assuming that Total Inorganic Carbon is mainly bound by calcium carbonates $\left(\mathrm{CaCO}_{3}\right)$, Total Organic Carbon (TOC) was calculated using the following equation: $\mathrm{TOC}(\%)=\mathrm{TC}(\%)-\mathrm{CaCO}_{3}(\%) * 12 / 100$.

High-resolution semi-quantitative geochemical analysis was carried out using an X-ray fluorescence (XRF) core scanner ITRAX (Cox Analytical Systems) at CEREGE with a $1 \mathrm{~mm}$ spatial resolution. The relative abundances of $\mathrm{K}, \mathrm{Ti}, \mathrm{Fe}, \mathrm{Ca}$ and $\mathrm{S}$ were measured using a chromium source $(35 \mathrm{kV}, 45 \mathrm{~mA})$ and an integration time of $15 \mathrm{~s}$. To compare XRF results with the discrete quantitative elemental concentrations obtained by an ICP-AES, ten XRF data points were averaged to gain $1 \mathrm{~cm}$-resolution measurements (Böning et al., 2007).

\subsection{Pollen analysis}

Pollen grains were extracted at IMBE (France) from 83 samples (each with a constant volume of $4 \mathrm{~cm}^{3}$ ) following the protocol of Faegri and Iversen (1989). Residues were sieved over 10 and $160 \mu \mathrm{m}$ meshes, mixed with glycerol and mounted on slides. Taxonomic identification was carried out under a $500 \times$ magnification oilimmersion microscope using a reference atlas (Reille, 1999). A minimum of 300 terrestrial pollen grains was counted per sample (average value of 450 grains). Taxa percentages were calculated on the terrestrial pollen sum.

\subsection{Diatom analysis}

53 samples were dried at $50{ }^{\circ} \mathrm{C}$ and weighed. Because diatom floras were composed of two species presenting sizes larger than $100 \mu \mathrm{m}$, Ellerbeckia arenaria and Campylodiscus hibernicus, we first carried out a count of these diatoms under a binocular microscope after sieving at a mesh of $100 \mu \mathrm{m}$. This step prevents underestimation of large-sized diatoms, which are typically fragmented during treatment and slide mounting (Petit-Maire et al., 1983). The remaining samples were incinerated at $500{ }^{\circ} \mathrm{C}$ in a muffle furnace for $30 \mathrm{~min}$ to remove organic matter (Vermeulen et al., 2012), then treated using standard procedures (rinsing in $10 \% \mathrm{HCl}$ and $30 \%$ $\mathrm{H}_{2} \mathrm{O}_{2}$ : water mixture, repeated rinsing with water), and the treatment was completed by high liquid-density separation $\left(\mathrm{ZnBr}_{2}\right.$ at a density of 2.0; Quesada et al., 2015). Slides were made using Naphrax as the mounting medium. A minimum of 400 valves per samples were counted using a Nikon Eclipse 80i light microscope (differential interference contrast optics, 1000× magnification, Refractive index $=1.25$ ). Diatom concentrations are expressed in valves $/ \mathrm{cm}^{3}$. Specimens were identified at their lowest taxonomic level (e.g., variety) following the species concept of Krammer and Lange-Bertalot (1986-1991) and the classification scheme of Round et al. (1990). Identification of Cyclotella was based on Hausmann and Lotter (2001) and Wunsam et al. (1995). Classification into ecological groups according to habitat, specific $\mathrm{pH}$ preference, and trophic requirements was also conducted (Krammer and Lange-Bertalot (1986-1991); Dam et al., 1994). Species diversity was estimated through species richness (number of species per sample).

\subsection{Ostracod analysis}

Half of the ALO11 core was sampled continuously every $5 \mathrm{~cm}$ (total of 271 samples) and sieved at meshes of 200 and $100 \mu \mathrm{m}$ to remove clay/silt particles (CEREGE and IMBE, France). Ostracods were picked out with a fine brush, cleaned of adhering sediments, rinsed with ethanol and dried in ambient air (Caporaletti, 2011). Samples were counted under a binocular microscope and identified using reference fauna of Western and Central Europe (Meisch, 2000). Given that the number of ostracods per sample was low (maximum of 36 valves), all ostracod valves were counted in each sample and the results expressed in concentrations (valves $/ \mathrm{cm}^{3}$ ).

\subsection{Statistical analysis}

For each individual dataset, a constrained hierarchical clustering was computed using the CONISS algorithm from the Rioja R package, and compared to the broken-stick model (Grimm, 1987; Bennett, 1996; Juggins, 2012). The significant geochemical, diatom, ostracod and pollen assemblage zones were respectively labelled GAZ, DAZ, OAZ and PAZ.

\section{Results}

\subsection{Lithostratigraphy}

The overall colour of ALO11 is light at the bottom of the core, and becomes darker toward the top. Between 14.11 and $13.1 \mathrm{~m}$, the sediment consists of coarse sand and gravel alternating with the massive homogeneous silt-clay that is characteristic of fluvialglacial deposits. The lake deposition starts at $13.1 \mathrm{~m}$ and consists of finely laminated layers. Four distinct lithotypes comprising lithostratigraphic units were encountered (Fig. 2A and B): flood layer (FL), matrix-supported layer (ML), dropstone layer (DL), and organic layer $(\mathrm{OL})$. These layers are described in Table 2. The lithotypes are grouped in three main lithostratigraphic units (Fig. 3). Unit $1(13.1-8.2 \mathrm{~m})$ is made of light grey sediment characterised by an alternation of graded and non-graded FL and of dropstone layers (restricted to the interval 13.1-12 m) (Fig. 2A). Unit 2 (8.2-4 m) consists of dark green sapropelic sediment (yellow OL) in alternation with FL. Between 6 and $4.5 \mathrm{~m}$, the OL are thicker on average compared with the other layers in the core (Fig. 2B). Unit 3 (4-0 m), which is light brown, consists of thick FL alternating with yellow OL.

\subsection{Chronology and sedimentation rate}

Radiocarbon ages and the age-depth model are presented in Table 1 and Fig. 3. Two samples appear too old, probably due to material reworking. Sample SacA-21327 (terrestrial debris at $85.5 \mathrm{~cm}$ ), which was sampled in a detrital layer, could have been reworked from the erosion of fan-delta sediments (500 years older). Poz-50231 (660 cm, Salix twig) is 4000 years older than the neighbouring ages, suggesting long-term catchment sequestration. At the core bottom, one or two ages are also inconsistent: either Poz-49768 $(8930 \pm 50 \mathrm{BP}, 1140 \mathrm{~cm})$ or Poz-46757 $(9380 \pm 50 \mathrm{BP}$, $1038 \mathrm{~cm})$, and Poz-63967 $(11,000 \pm 140 \mathrm{BP}, 1260 \mathrm{~cm})$. The most probable explanation is a contamination of Poz-49768 by recent material due to its low carbon weight $(0.4 \mathrm{mgC})$ whereas the other ages are consistent with dates on well-identified terrestrial remains and with a constant sedimentation rate over Unit 2. Thus, SacA21327, Poz-50231 and Poz-49768 were excluded from the agedepth model.

ALO11 spans the last $13,060-13,630 \mathrm{cal}$. BP $(2 \sigma)$. Average age uncertainties $(2 \sigma)$ are 360 years from 8500 to 13,300 cal. BP, 150 
Table 2

Classification of the lithotypes of core ALO11.

\begin{tabular}{|c|c|c|c|c|}
\hline Lithotype & Description & Thickness (mm) & Element composition & Interpretation \\
\hline Flood layer (FL) & $\begin{array}{l}\text { Normally graded grain-supported: } \\
\text { succession of } 3 \text { facies. Base: dark well- } \\
\text { sorted fine sand to medium silt. Sharp } \\
\text { contact with underlying layer (rarely } \\
\text { erosive). May contain plant remains. } \\
\text { Median zone: fining-upward coarse to } \\
\text { fine silts. Top: white clay cap. } \\
\text { Non-graded grain-supported: clastic } \\
\text { fine silts with no textural organization } \\
\text { or in a few cases very faint grading. }\end{array}$ & $\begin{array}{l}\text { Min: } 0.2 \\
\text { Max: } 151.6 \\
\text { Mean: } 5.7\end{array}$ & $\begin{array}{l}\text { Base: Ca, Mg, Si (silt/sand grains). } \\
\text { Top: Al, K, Si, Fe (clay). } \\
\text { Al, K, Si, Fe (clay) }\end{array}$ & $\begin{array}{l}\text { Detrital deposition induced by high- } \\
\text { velocity turbidity currents (Schillereff et al., } \\
\text { 2014). In the deeper sub-basin of Lake Allos } \\
\text { over the last } 1000 \text { years, FL develop from } \\
\text { homopycnal flows with spreading and } \\
\text { settling of sediment through the water } \\
\text { column (Wilhelm et al., 2015). } \\
\text { Distal detrital deposition by turbidity } \\
\text { currents (Czymzik et al., 2013). These layers } \\
\text { suggest a lower sediment supply in the } \\
\text { coring site that may be reflect low-intensity } \\
\text { rainfall or a poorly erosive catchment } \\
\text { context (Brisset et al., 2017). }\end{array}$ \\
\hline Matrix-supported layer (ML) & $\begin{array}{l}\text { Poorly sorted clastic deposits of } \\
\text { medium to fine silts. Rich in terrestrial } \\
\text { plant remains. Some ML contain the } \\
\text { epiphytic diatom Ellerbeckia arenaria } \\
\text { (Fig. 2-B2). The } 11 \text { ML layers are } \\
\text { randomly distributed. }\end{array}$ & $\begin{array}{l}\text { Min: } 0.4 \\
\text { Max: } 35.3 \\
\text { Mean: } 7.4\end{array}$ & $\begin{array}{l}\mathrm{Al}, \mathrm{K}, \mathrm{Si}, \mathrm{Fe} \text { (clay matrix); } \\
\mathrm{Ca}, \mathrm{Mg}, \mathrm{Si} \text { (silt/sand grains) }\end{array}$ & $\begin{array}{l}\text { Gravity-reworked sediment deposition due } \\
\text { to slope failure of delta foresets (Arnaud } \\
\text { et al., 2002; Petersen et al., 2014). A good } \\
\text { correlation between ML layer and FL in Lake } \\
\text { Ammersee (Czymzik et al., 2013) suggests } \\
\text { that ML may originate from erosion of } \\
\text { unconsolidated shallow sediments during } \\
\text { floods. }\end{array}$ \\
\hline Dropstone layer (DL) & $\begin{array}{l}\text { Grey silt-clay, rhythmic layer } \\
\text { containing isolated heterometric clastic } \\
\text { particles (sand to medium silts). }\end{array}$ & Max: 0.2 & $\begin{array}{l}\mathrm{Si}, \mathrm{Na}, \mathrm{Fe}, \mathrm{Mg} \text { (silt/sand grains). } \\
\mathrm{Si}, \mathrm{Al}, \mathrm{K} \text { (clay matrix). }\end{array}$ & $\begin{array}{l}\text { Clastic deposition in a glaciolacustrine } \\
\text { context (Livingstone et al., 2015). Following } \\
\text { Brauer and Casanova (2001), DL are likely to } \\
\text { originate from calving of icebergs and } \\
\text { related ice-rafting in a context of a } \\
\text { deglaciated lake, while clay deposition } \\
\text { occurred from meltwater plume settling } \\
\text { during more quiet water conditions in a } \\
\text { periodically frozen lake. }\end{array}$ \\
\hline Organic layer (OL) & $\begin{array}{l}\text { Matrix-supported yellow to black } \\
\text { sapropel rich in amorphous organic } \\
\text { matter. Bioturbation features }<10 \mu \mathrm{m} \\
\text { may occur (Fig. 2-B1). Some OL contain } \\
\text { benthic diatoms Campylodiscus } \\
\text { hibernicus }\end{array}$ & $\begin{array}{l}\text { Min: } 0.1 \\
\text { Max: } 54 \\
\text { Mean: } 2.3\end{array}$ & $\begin{array}{l}\text { C, O (organic matter). } \\
\text { S (pyrite, greigite) }\end{array}$ & $\begin{array}{l}\text { Sapropelic OL may originate from either } \\
\text { algal or bacterial elements, or } \\
\text { decomposition of land and aquatic plants } \\
\text { (Schnurrenberger et al., 2003). }\end{array}$ \\
\hline
\end{tabular}

years from 1700 to 8500 cal. BP and 100 years from present-day to $1700 \mathrm{cal}$. BP. The total sedimentation rate and the organic sedimentation rate show notable variations $(0.8-0.1 \mathrm{~cm} / \mathrm{yr})$ (Fig. 3$)$. The total sedimentation rate is high $(0.12 \mathrm{~cm} / \mathrm{yr})$ from 13.1 to $8.2 \mathrm{~m}$ and drops to a minimum of $0.05 \mathrm{~cm} / \mathrm{yr}$ from 8.2 to $5.25 \mathrm{~m}$. Half of the accumulated sediment is composed of organic matter $(0.02 \mathrm{~cm} / \mathrm{yr})$ and the other half of detrital matter $(0.03 \mathrm{~cm} / \mathrm{yr})$ until $5.25 \mathrm{~m}$. Between 5.25 and $4.75 \mathrm{~m}$, organic sedimentation attains its maximum rate $(0.17 \mathrm{~mm} / \mathrm{yr})$. From $4 \mathrm{~m}$ to the top of the core, the total sedimentation rate increases abruptly to $0.34 \mathrm{~mm} / \mathrm{yr}$. This value is dominated by a high detrital sediment supply $(0.30 \mathrm{~mm} / \mathrm{yr})$, whereas the organic contribution is low (Fig. 4).

\subsection{Geochemical composition of the bulk sediment}

Bulk sediments are primarily composed of $\mathrm{SiO}_{2}$ (ranging from 55 to $63 \%), \mathrm{Al}_{2} \mathrm{O}_{3}(18-21 \%)$ and $\mathrm{CaO}(0.8-10 \%)$. Cross-correlations between $\mathrm{Al}_{2} \mathrm{O}_{3}, \mathrm{SiO}_{2}, \mathrm{~K} 2 \mathrm{O}, \mathrm{MgO}, \mathrm{Fe}_{2} \mathrm{O}_{3}$, and $\mathrm{TiO}_{2}$ are highly positive (Table 3 ). These elements are strongly and negatively correlated with $\mathrm{CaO}$ (correlation coefficient to $\mathrm{SiO}_{2}$ is -0.86 and to $\mathrm{Al}_{2} \mathrm{O}_{3}$ is -0.72 ; Table 3 ) and moderately negatively with $\mathrm{Na}_{2} \mathrm{O}$. TOC (Total Organic Carbon) and TN (Total Nitrogen) are moderately positively correlated with the Al-Si elemental association and negatively with $\mathrm{CaO}$. A third strong covariant association including $\mathrm{MnO}$ and $\mathrm{P}_{2} \mathrm{O}_{5}$ stands apart $(r=0.69)$, having no significant correlation with other elements. Finally, TS is moderately correlated with $\mathrm{Fe}_{2} \mathrm{O}_{3}(\mathrm{r}=0.47)$.

The opposition between $\mathrm{Al}_{2} \mathrm{O}_{3}-\mathrm{SiO}_{2}$ and $\mathrm{CaO}$ reflects the main vertical variation in geochemical assemblage zones based on clustering (GAZ; Fig. 4). GAZ 1 is characterised by higher values of $\mathrm{Al}_{2} \mathrm{O}_{3}$,
$\mathrm{K}_{2} \mathrm{O}, \mathrm{TiO}_{2}, \mathrm{MgO}$ and $\mathrm{SiO}_{2}$, whereas $\mathrm{CaO}$ and $\mathrm{TOC}$ are at a minimum TS concentrations are at a maximum $(0.6 \%)$ in this zone. GAZ 2 is characterised by relatively lower concentrations of $\mathrm{Al}_{2} \mathrm{O}_{3}$ and $\mathrm{SiO}_{2}$ and maximum values of $\mathrm{CaO}(8.6 \%)$, although $\mathrm{TOC}$ remains nearly null. Mean concentration in $\mathrm{MnO}$ is relatively high, whereas concentrations of TS and $\mathrm{Fe}_{2} \mathrm{O}_{3}$ are low. Two samples at 991 and $911 \mathrm{~cm}$ present a different pattern: concomitantly high TS and $\mathrm{Fe}_{2} \mathrm{O}_{3}$, associated with low $\mathrm{MnO}$. GAZ 3 is characterised by a decrease in values of $\mathrm{Na}_{2} \mathrm{O}$ (except for one sample that had the maximum $\mathrm{Na}_{2} \mathrm{O}$ value) and a progressive diminution of $\mathrm{CaO}$ replaced by increases in $\mathrm{Al}_{2} \mathrm{O}_{3}, \mathrm{~K} 2 \mathrm{O}, \mathrm{TiO}_{2}$ and $\mathrm{SiO}_{2}$. TOC and TN increase respectively from 0.5 to $1.3 \%$, and from 0.1 to $0.3 \%$ along this zone. Background mean values in TS are higher than in GAZ 2 (0.1\%). GAZ 4 presents higher $\mathrm{Al}_{2} \mathrm{O}_{3}, \mathrm{~K}_{2} \mathrm{O}, \mathrm{TiO}_{2}$ and $\mathrm{SiO}_{2}$, associated with a maximum of TOC and TN (respectively 2.2 and $0.7 \%$ ), and minimum $\mathrm{CaO}$ and $\mathrm{MnO}$ contents. Na2O is relatively lower in this zone. Finally, GAZ $\mathbf{5}$ is characterised by a high element variability. Mean values of $\mathrm{Al}_{2} \mathrm{O}_{3}, \mathrm{~K}_{2} \mathrm{O}$, $\mathrm{TiO}_{2}, \mathrm{SiO}_{2}$ and TOC are higher. This unit is also marked by a reincrease in $\mathrm{CaO}$ and $\mathrm{MnO}$. TS and $\mathrm{Fe}_{2} \mathrm{O}_{3}$ peak jointly between 220 and $200 \mathrm{~cm}$. The top sample $\left(1.7 \mathrm{~cm}\right.$ depth) has high $\mathrm{MnO}$ and $\mathrm{P}_{2} \mathrm{O}_{5}$ (threefold compared to the entire core).

\subsection{High-resolution logging}

XRF intensities of $\mathrm{Ca}, \mathrm{K}, \mathrm{Fe}$, Ti and $\mathrm{S}$ ( $1 \mathrm{~mm}$ of resolution) show a visual match with quantitative concentration changes (Fig. 4). A significant correlation is found for $\mathrm{Ca}(\mathrm{r}=0.75)$, but not for $\mathrm{K}, \mathrm{Ti}$ and $\mathrm{S}$. The lack of significant correlation between the XRF and ICP-AES results is probably due to different sampling resolutions, 


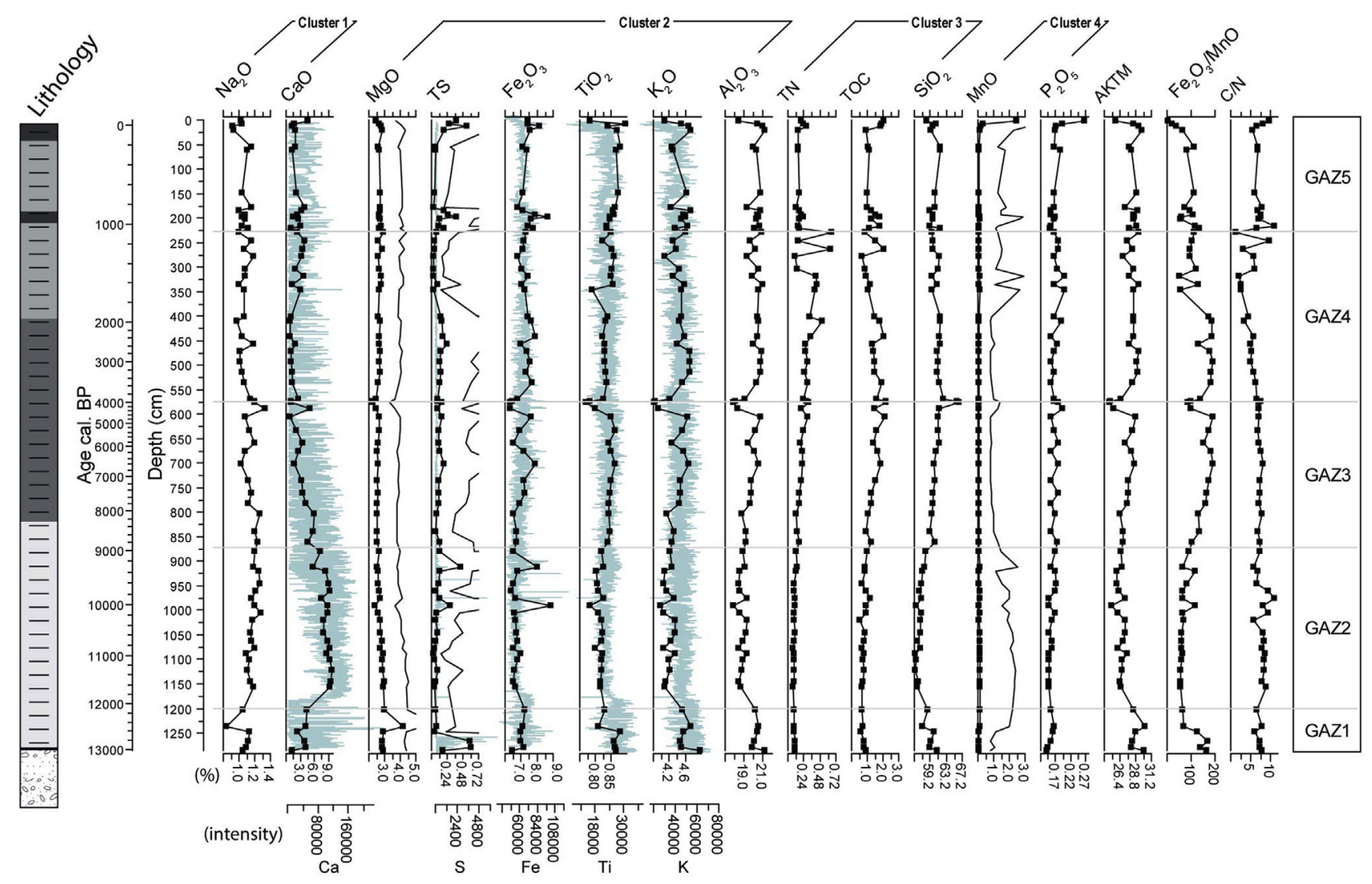

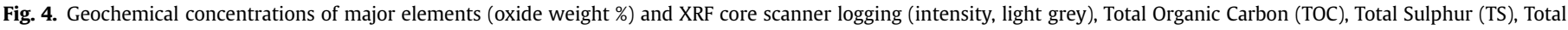

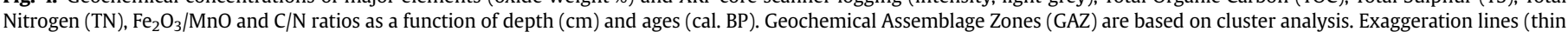
black lines) are drawn for selected elements.

Table 3

Correlation matrix of the element composition of bulk sediments of ALO11. Significant values at a threshold of $1 \%$ are shaded (positive values in bold).

\begin{tabular}{|c|c|c|c|c|c|c|c|c|c|c|c|c|}
\hline & $\mathrm{SiO}_{2}$ & $\mathrm{Al}_{2} \mathrm{O}_{3}$ & $\mathrm{Fe}_{2} \mathrm{O}_{3}$ & $\mathrm{MnO}$ & $\mathrm{MgO}$ & $\mathrm{CaO}$ & $\mathrm{Na}_{2} \mathrm{O}$ & $\mathrm{K}_{2} \mathrm{O}$ & $\mathrm{TiO}_{2}$ & $\mathrm{P}_{2} \mathrm{O}_{5}$ & $\mathrm{TN}$ & TOC \\
\hline $\mathrm{Al}_{2} \mathrm{O}_{3}$ & 0.32 & 1.00 & & & & & & & & & & \\
\hline $\mathrm{Fe}_{2} \mathrm{O}_{3}$ & 0.08 & 0.47 & 1.00 & & & & & & & & & \\
\hline $\mathrm{MnO}$ & -0.12 & -0.19 & 0.09 & 1.00 & & & & & & & & \\
\hline $\mathrm{MgO}$ & -0.42 & 0.32 & -0.02 & -0.09 & 1.00 & & & & & & & \\
\hline $\mathrm{CaO}$ & -0.86 & -0.72 & -0.43 & 0.06 & 0.13 & 1.00 & & & & & & \\
\hline $\mathrm{Na}_{2} \mathrm{O}$ & -0.12 & -0.78 & -0.52 & -0.13 & -0.52 & 0.53 & 1.00 & & & & & \\
\hline $\mathrm{K}_{2} \mathrm{O}$ & 0.14 & 0.94 & 0.44 & -0.16 & 0.42 & -0.57 & -0.79 & 1.00 & & & & \\
\hline $\mathrm{TiO}_{2}$ & 0.23 & 0.68 & 0.20 & -0.25 & 0.15 & -0.46 & -0.33 & 0.59 & 1.00 & & & \\
\hline $\mathrm{P}_{2} \mathrm{O}_{5}$ & 0.24 & -0.07 & 0.06 & 0.69 & -0.23 & -0.21 & -0.04 & -0.19 & -0.16 & 1.00 & & \\
\hline TN & 0.48 & 0.39 & 0.29 & -0.01 & -0.13 & -0.55 & -0.39 & 0.24 & 0.08 & 0.33 & 1.00 & \\
\hline TOC & 0.64 & 0.20 & 0.33 & 0.20 & -0.41 & -0.61 & -0.24 & 0.14 & -0.02 & 0.35 & 0.54 & 1.00 \\
\hline TS & 0.04 & 0.13 & 0.47 & 0.25 & -0.07 & -0.19 & -0.20 & 0.19 & 0.08 & 0.04 & -0.02 & 0.20 \\
\hline
\end{tabular}

heterogeneity of sediments and matrix/grain-size effects on XRF measurements (Böning et al., 2007): XRF results are based on surface sediment analysis at $1 \mathrm{~mm}$ resolution whereas ICP-AES results were obtained from $1 \mathrm{~cm}$-thick sediment slices. At the millimetrescale, ALO11 is characterised by a succession of flood layers (FL) implying grain-size variations. SEM element mapping shows that Ca is enriched in the coarse silt to fine sands of the basal part of FL (Fig. 2), whereas $\mathrm{K}$ and $\mathrm{Ti}$ are enriched in the upper FL clay cap (Cuven et al., 2010). This is well-evidenced by the high-resolution variability of the XRF element profiles.

\subsection{Pollen record}

Pollen are present from $1350 \mathrm{~cm}$ to the top of the core; therefore, the pollen record covers the last ca. 13,500 years. 125 taxa were identified. The simplified pollen diagram in Fig. 5 represents only the main taxa that were locally present in the watershed (except for Cerealia, Juglans, Castanea and Olea, which could be considered as extra-local) and in the lower part of the valley (from the montane zone, with mixed oak forests). From 1350 to $1275 \mathrm{~cm}$, pollen grains are rare and not sufficiently well-preserved to support palynostratigraphical interpretations. PAZ 1a is characterised by the abundance of corroded Artemisia and Pinus grains while pollen diversity remains very low (below 12 taxa). Thus, PAZ 1a does not necessarily reflect with accuracy past vegetation communities during this period, and may suggest potential reworking of sediments preceding lake formation. According to the age-depth model and the regional palynostratigraphy, the pollen record of Allos 


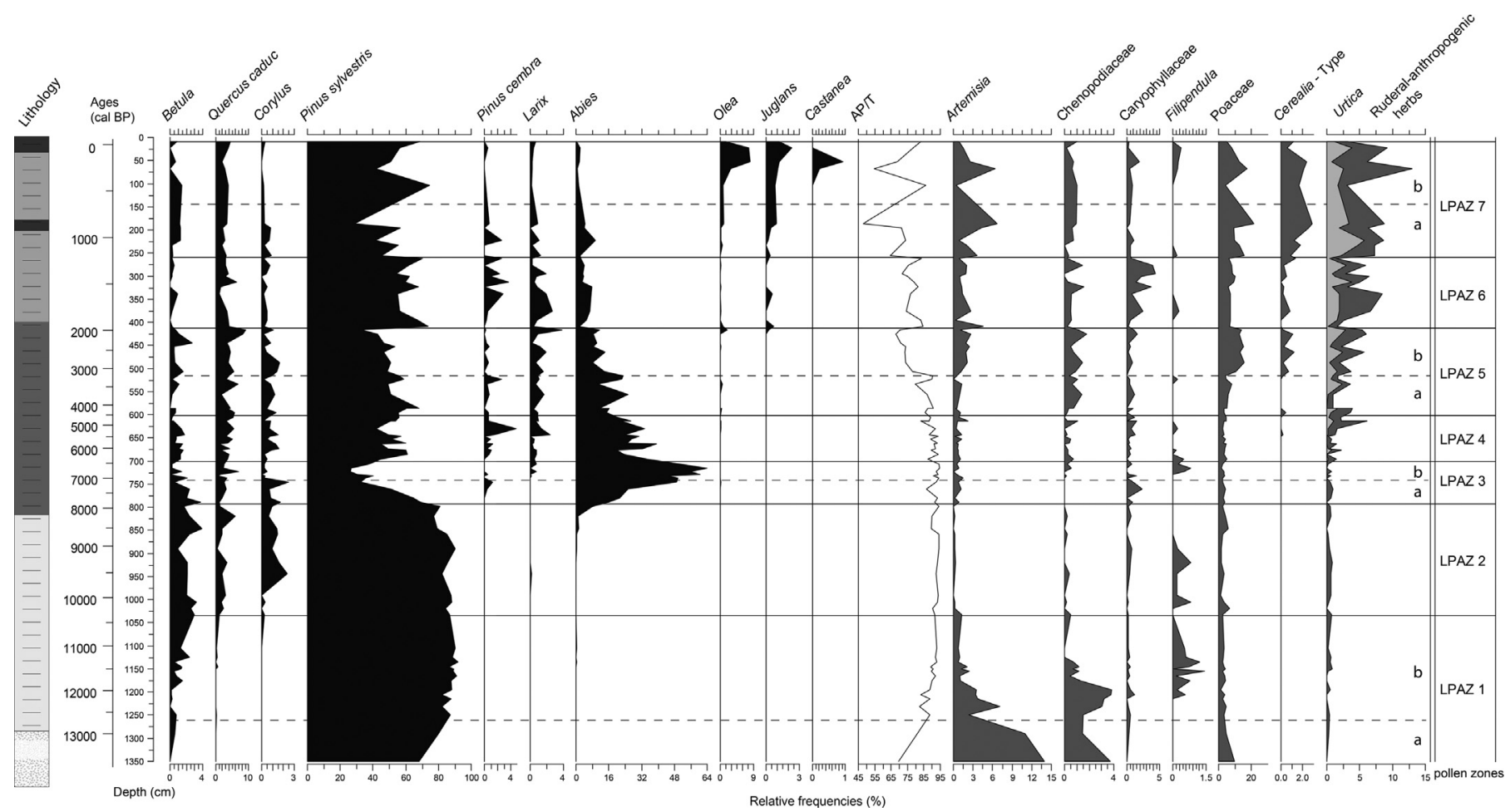

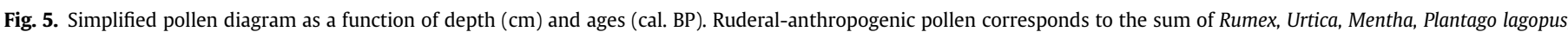

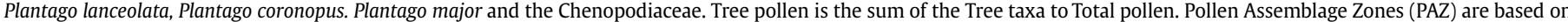
cluster analysis.

(from PAZ 1b) documents vegetation dynamics since the Younger Dryas.

PAZ 1b is characteristic of the pollen assemblages in mountain pollen records during the climatic reversal of the Younger Dryas, with the predominance of steppe grasslands comprising Poaceae, Artemisia, and several ruderal taxa, such as Chenopodiaceae. Filipendula is also well-recorded in a continuous pollen curve. PAZ 2 is marked by a general diminution of grass percentages whereas Pinus remains over-abundant, associated with Betula, which raises its optimum (Fig. 5), as classically recorded at the Lateglacial/Holocene transition in the Alps. Corylus and Quercus are represented by continuous pollen curves. The end of the zone is also characterised by the beginning of a continuous curve of Abies. During PAZ 3, Abies percentages increase (PAZ 3a), reaching a maximum in PAZ 3b. The first continuous occurrences of Larix are observed in PAZ $\mathbf{3 b}$. This major change in the tree pollen assemblages is associated with the lowest values of Pinus, type sylvestris, observed in the record. The first occurrences of Pinus cembra are recorded in PAZ 3a. Artemisia percentages increase progressively from that period. During PAZ 4, Abies percentages decrease drastically whereas Larix remains stable, and ruderal-anthropogenic pollen increases slightly. Chenopodiaceae are present quite continuously from that period. From PAZ 5, Abies percentages decrease further, whereas Pinus remains relatively stable. Pinus cembra increases slightly. A progressive reexpansion of Artemisia, Chenopodiaceae, and Poaceae, together with other ruderal taxa, occurs, marked by a significant decline in the AP curve during PAZ 5b. The onset of this latter zone is characterised by the first continuous occurrences of Cerealia (Fig. 5). PAZ 6 is marked by a decrease of Abies, whereas the anthropogenic pollen assemblages with Urtica and other ruderal taxa (Plantago and Rumex) become predominant among grasses (an increase of Caryophyllaceae is also observed in PAZ 6). The relative frequencies of Larix remain stable and Pinus briefly increases, which increases the tree pollen sum. The last zone (PAZ 7a, $7 \mathbf{7 b})$ is marked by a general decline in tree pollen (Pinus excepted) and by the highest percentages of grasses, such as Artemisia, Poaceae, Chenopodiaceae and the ruderal-anthropogenic species (sum of Rumex, Urtica, Mentha, Plantago lagopus, Plantago lanceolata, Plantago coronopus, Plantago major and the Chenopodiaceae). The pollen type Cerealia, which attains its maximum in this zone, is accompanied by peaks of Olea, Juglans and Castanea.

\subsection{Diatom record}

Diatoms were observed in the sediments from $741 \mathrm{~cm}$ to the top of the core. A total of 88 species was identified (Fig. 6). From 745 to $365 \mathrm{~cm}$, diatom concentrations (average of 4200 valves $/ \mathrm{cm}^{3}$ ) are high enough for a significant count to be carried out. From $365 \mathrm{~cm}$ to $0 \mathrm{~cm}$, diatom richness is very variable, from 0 to 8000 valves $/ \mathrm{cm}^{3}$. From 750 to $530 \mathrm{~cm}$ (DAZ 1 and 2), sediments are rich in benthic species, Ellerbeckia arenaria and Gomphonema sp. 1 (15\%). The mean abundance of E. arenaria is 50\% in DAZ 1 and 25\% in DAZ 2. The abundance of Puncticulata bodanica var. lemanica increases in DAZ 2, approaching up to $60 \%$ of total diatoms. Associated species are Cyclotella rosii, Cyclotella comensis and Diploneis elliptica (Fig. 6). Species richness progressively increases. In DAZ 2, alkaliphilous species are progressively replaced by circum-neutral species. Oligotrophic diatoms are dominant, but some eutrophic species are also present in smaller numbers. From 605 to $595 \mathrm{~cm}$, one sample shows very high diatom concentrations $\left(46,000\right.$ valves $\left./ \mathrm{cm}^{3}\right)$. Diatom species richness is higher, and assemblages are composed of $E$. arenaria, $P$. bodanica var. lemanica and associated species, such as C. comensis, C. rosii, Cyclotella cyclopuncta, Cocconeis placentula var. euglypta, D. elliptica. From 590 to $530 \mathrm{~cm}$, a high variability in the abundances of $E$. arenaria and $P$. bodanica var. lemanica occurs. Two samples with the highest E. arenaria abundances (>90\%) are 


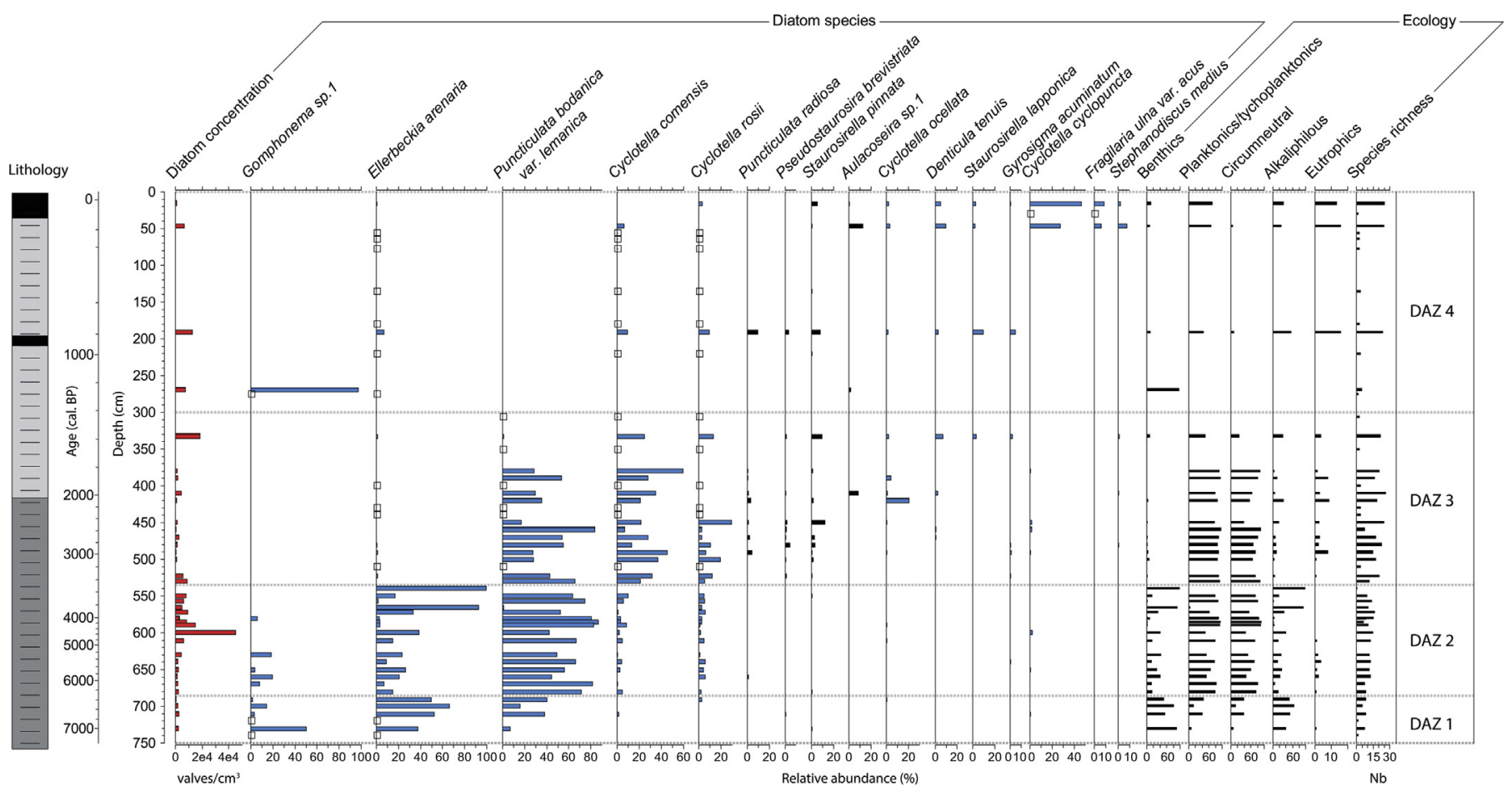

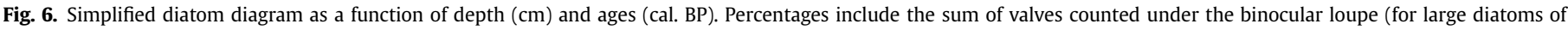

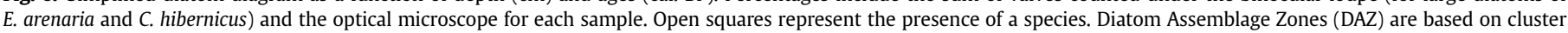

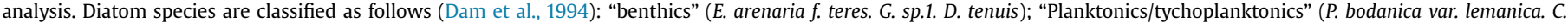

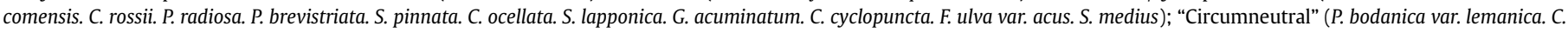

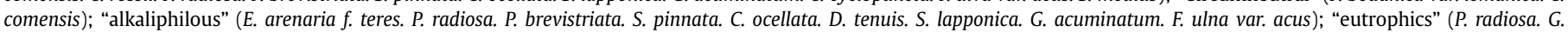
acuminatum. F. ulna var. acus. S. medius).

present at 566 and $540 \mathrm{~cm}$ depth. Here, diatom species richness is lower, and alkaliphilous diatoms are more abundant. From 530 to $300 \mathrm{~cm}$ (DAZ 3), assemblages are mainly composed of planktonic species and are characterised by the disappearance of $E$. arenaria and the development of $C$. comensis and $C$. rosii. Higher abundances of Pseudostaurosira brevistriata, Staurosirella pinnata, and Puncticulata radiosa occur. Assemblages are dominated by circum-neutral species and eutrophic diatoms are present (e.g., P. radiosa, G. acuminatum, S. medius). From $300 \mathrm{~cm}$ to the top (DAZ 4), diatom concentrations are low, except for four samples at 17, 47, 191 and $270 \mathrm{~cm}$ depth. DAZ 4 is marked by the disappearance of $P$. bodanica var. lemanica in the record. Assemblages are composed of Cyclotella comensis, Cyclotella rosii, and Staurosirella pinnata. Only few valves of $E$. arenaria are present. The sample at $270 \mathrm{~cm}$ depth is composed almost exclusively of a benthic species of the genus Gomphonema (sp. 1) (>95\%). The sample at $191 \mathrm{~cm}$ depth is characterised by high diatom species richness (24 species), notably alkaliphilous (57\%) and eutrophic species (15\%). Finally, from $51 \mathrm{~cm}$ to the top of the core, assemblages are mainly dominated by planktonic diatoms, such as C. cyclopuncta, Fragilaria ulva var. acus, Aulacoseira sp. 1. Diatom species richness is high and eutrophic species remain abundant (15\%), as in the previous unit.

\subsection{Ostracod record}

Ostracod diversity is relatively low; only four species were encountered in the core (Fig. 7). From 1355 to $1192 \mathrm{~cm}(\mathbf{O A Z ~ 1 )}$, samples are characterised by low ostracod concentrations (1.28 $.10^{-2}$ valves $/ \mathrm{cm}^{3}$ ), only comprising Cytherissa lacustris. The highest ostracod concentrations (mean $1.70 .10^{-1}$ valves $/ \mathrm{cm}^{3}$ ) of the core are from 1192 to $1155 \mathrm{~cm}(\mathbf{O A Z} 2)$. A few valves of Cypridopsis vidua

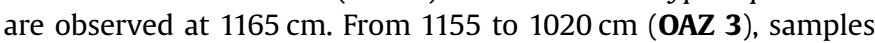

are composed of some valves of $C$. lacustris. Ostracod concentrations are very low $\left(2.02 .10^{-2}\right.$ valves $\left./ \mathrm{cm}^{3}\right)$, and many samples are

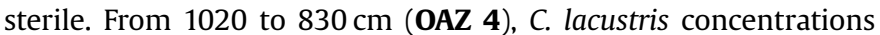
rebound to $7.44 .10^{-2}$ valves $/ \mathrm{cm}^{3}$. Some valves of $C$. vidua are present at the end of the unit. From 830 to $175 \mathrm{~cm}$ (OAZ 5), the ostracod concentration is very low $\left(1.42 .10^{-2}\right.$ valves $\left./ \mathrm{cm}^{3}\right)$ and is effectively zero between 635 and $480 \mathrm{~cm}$. Assemblages are dominated by $C$. lacustris. Some valves of $C$. vidua and Candona candida occur at the beginning and the end of the unit. The first occurrences of Cypria ophthalmica are observed from 320 to $220 \mathrm{~cm}$. Finally, between $175 \mathrm{~cm}$ and the top (OAZ 6), the samples are characterised by relatively abundant $C$. ophthalmica.

\section{Interpretation and discussion}

This section presents a chronological division including all the environmental proxies in order to discuss major changes in the watershed history and the processes linking the terrestrial and aquatic ecosystems (period A-E). Fig. 8 summarises the main indicators of environmental change deduced from the various compartments of the watershed. The use of common intra-Holocene stratigraphic boundaries for all compartments is then discussed together with synchronicity and divergence of trajectories of compartment development identified from biotic and abiotic indicators of external forcing.

\subsection{Palaeoenvironmental history}

\subsubsection{Period A (13,500-12,000 cal. BP): early lake sedimentation} dominated by glaciofluvial processes

The formation of Lake Allos took place around 13,500 cal. BP (Fig. 8), in the same time interval as other lakes in several high- 


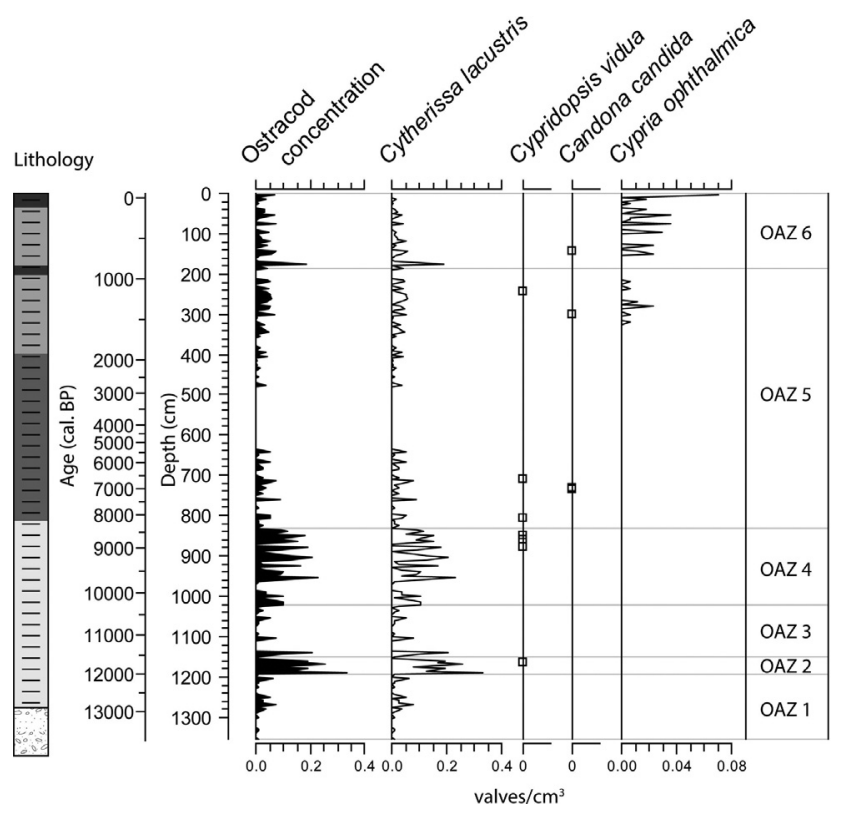

Fig. 7. Ostracod diagram as a function of depth $(\mathrm{cm})$ and ages (cal. BP). Open squares represent the presence of a species. Ostracod concentration is given in valves per $\mathrm{cm}^{3}$. Ostracod Assemblage Zones (OAZ) are based on cluster analysis.

altitude cirques of the Southern Alps that formed from 14,500 to 13,000 cal. BP (Brisset et al., 2015). Lacustrine sedimentation commenced with fine light grey laminations and a high total accumulation rate $(0.12 \mathrm{~cm} /$ year $)$. The bulk sediment was dominated by aluminosilicate elements $\left(\mathrm{Al}_{2} \mathrm{O}_{3}\right.$ of $20.5 \%$ and $\mathrm{SiO}_{2}$ of $\left.60 \%\right)$, whereas TOC was nearly null (Fig. 4), indicating a high inorganic sediment supply at that time. Detrital sedimentation was characterised by the regular deposition of normally graded flood layers that are indicative of frequent torrential activity in the lake catchment (Fig. 2). Homogeneous silt-clay sediments containing isolated clasts and alternating with the flood layers may indicate both ice calving of the latest glacier in the lake catchment and terrigenous supply during periods of lake surface freezing (possibly through avalanches from the steep southern and eastern slopes bordering the lake). Light-blue clays to beige silt facies are commonly found in the deepest sections of lake sediment cores from the Mediterranean Alps (e.g. Lake Long Inférieur: Ponel et al., 2001). In Lake Vens, as in Lake Allos, they are characterised by high sedimentation rates associated with important minerogenic supply identified by magnetic susceptibility (Brisset et al., 2015). Over this period, high TS concentrations and a high $\mathrm{Fe}_{2} \mathrm{O}_{3} / \mathrm{MnO}$ ratio (Naeher et al., 2013), together with the presence of pyrite and greigite minerals in thin slides, suggest a poor oxygenation of the deep waters of the lake. Aquatic fossil content was generally low, characterised by few ostracod valves of C. lacustris (Fig. 8) living in fresh and oligotrophic waters at the sediment-water interface (Meisch, 2000). An abundant detrital supply should have favoured water mixing, but all proxies indicate rather that long periods of lake surface freezing took place, limiting water mixing and light penetration, and thus creating unfavourable conditions for the establishment of lake biota. Despite a typical over-representation of Pinus during the Lateglacial period, steppe plants such as Artemisia, Chenopodiaceae, and Poaceae were well-represented in the watershed of Lake Allos. Overall, this period probably reflects the last stage of cirque glacier melting upstream of the lake that could correspond to the lowest terminal moraines deposited in the catchment at $2310 \mathrm{~m}$ a.s.l (Jorda, 1975; Brisset et al., 2014a,b). These periglacial conditions led to an abundant minerogenic sediment supply at a time when slopes were not completely protected by steppe vegetation.

Within this period, maximal frequencies of Artemisia and Chenopodiaceae pollen between 12,900 and 11,800 cal. BP likely reflect a vegetation reversal during the cooling episode of the Younger Dryas corresponding approximately to the INTIMATE chronological boundaries (12,900-11, $500 \mathrm{cal}$. BP; Blockley et al., 2012). The timing of this event at Allos also matches well with in-situ exposure dating of terminal moraines in the eastern part of the French-Italian Maritime Alps (Federici and Stefanini, 2001). The same vegetation reversals during the last stage of the deglaciation have been recorded in several lakes located in glacier cirques above $2000 \mathrm{~m}$ a.s.l. in the Mediterranean Alps (e.g., Lake Long Inférieur (Ponel et al., 2001); Orgials (Ortu, 2002); Vei del Bouc (Finsinger, 2001); Vallon de Provence, Vallon du Loup and Restefond (Beaulieu de, 1977); Terres Plaines, Vens (Brisset et al., 2015)). Moreover, chironomid taxa having affinity with very cold waters (i.e. Paracladius Hirvenoja) occurred exclusively during that period in Lake Long Inférieur (Gandouin and Franquet, 2002), thus confirming that the Younger Dryas climatic event drastically impacted both terrestrial and aquatic ecosystem dynamics in the Mediterranean Alps.

\subsection{Period B (12,000-8600 cal. BP): a decisive change in detrital supply for aquatic living conditions}

The total sediment accumulation rate remained high $(0.11 \mathrm{~cm} /$ year) at the beginning of the Holocene. Organic matter contribution was minimal (TOC of $1 \%$ ) and characterised mostly by a terrigenous origin as indicated by a high C/N ratio (Meyers and Teranes, 2001). Characterised by the first occurrences of tree macroremains (Salix twig dated at 10,160-9710 cal. BP, Table 1), the pollen assemblage was dominated by Pinus sylvestris type (90\%) associated with Betula, while grass taxa reached their lowest values (Fig. 5), suggesting the development of a pioneer tree cover in the lake catchment. At lower elevations, hazel and mixed oak forests probably prevailed (as suggested by the continuous pollen curves of Quercus and Corylus from 10,100 cal. BP). Even though this period was still characterised by dominance of the minerogenic supply, a change in the bulk sediment geochemistry occurred, characterised by a decline in aluminosilicate elements associated with higher $\mathrm{CaO}$ (Fig. 8). This decrease in the aluminosilicate fraction at Allos is very likely in line with the drop to lower values of magnetic susceptibility at Lake Vens in the same period (Brisset et al., 2015). Calcium occurred in two sedimentary fractions, one minerogenic with silt and fine sand particles deposited in detrital layers (Fig. 3A), and the other biogenic as evidenced by the maximal valve concentration of C. lacustris (ostracod). Relative enrichment in $\mathrm{MnO}$ associated with low $\mathrm{Fe}_{2} \mathrm{O}_{3} / \mathrm{MnO}$ indicates that deep waters were more oxic compared to the previous period, which is in agreement with the ecological affinity of $C$. lacustris.

The higher contribution in Ca from the lake catchment during a period of enhanced oxygenation of the lake waters probably had a major influence on the expansion of $C$. lacustris, creating favourable conditions for calcified organisms. In freshwaters, calcium is a critical limiting environmental factor for crustacean carapace development (Mezquita et al., 1999; Lampert and Sommer, 2007). This implies that calcium was bio-available, i.e., present in its dissolved form $\left(\mathrm{Ca}^{2+}\right)$ in the lake waters.

Calcium may come from many sources in the Lake Allos catchment, and through different geomorphic processes: (1) glacial erosion of sandstones; (2) hydrological mechanical erosion processes affecting easily erodible marl and limestone deposits; (3) hydric chemical weathering through karst formation and soil weathering. Due to the strong spatial heterogeneity of sediment sources, detrital inputs were probably mixed. However, considering 
Age (cal. BP)

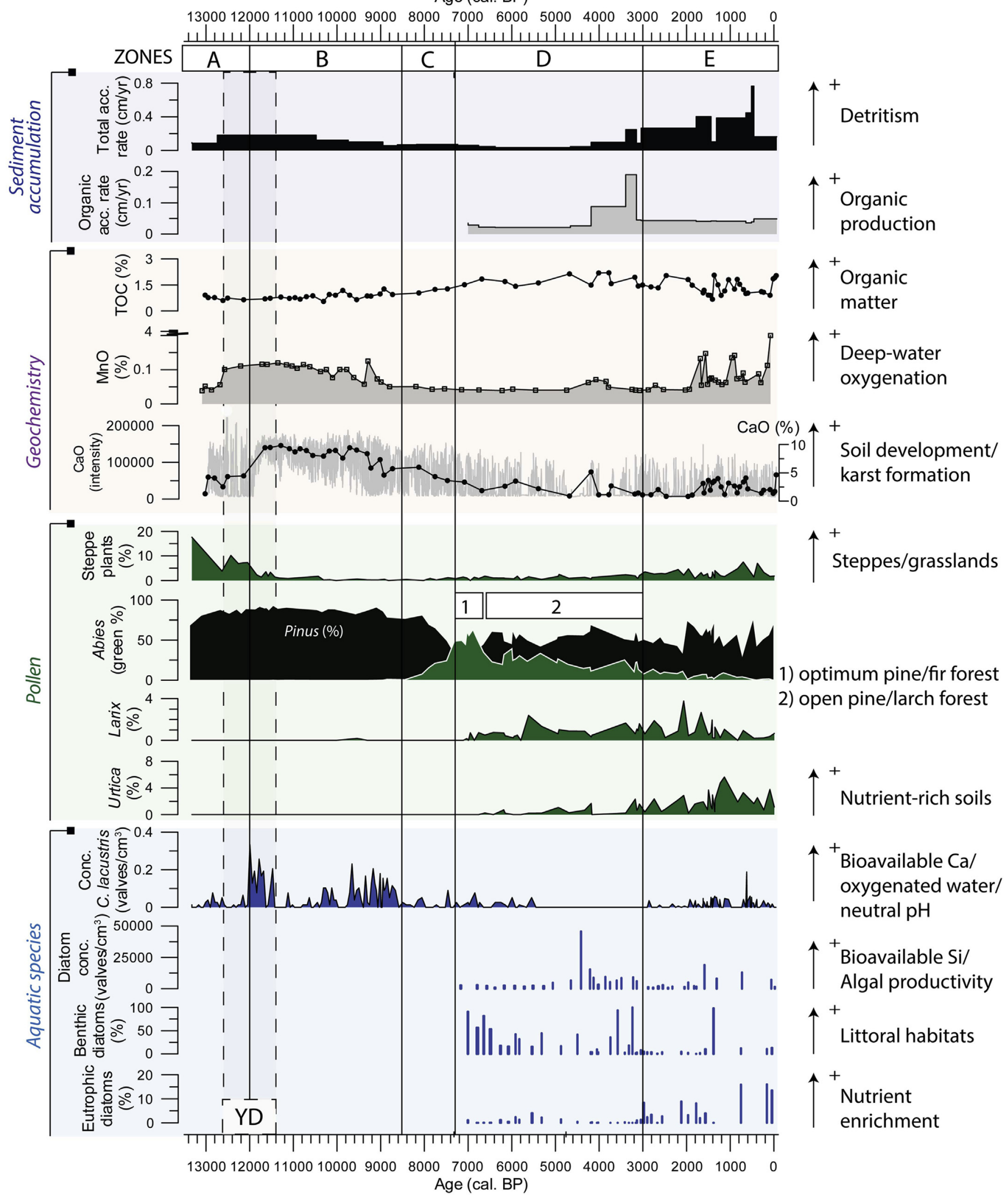

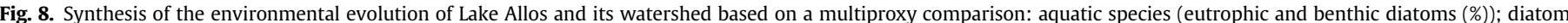

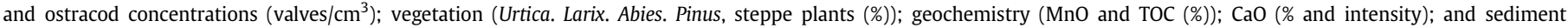
accumulation (organic and total accumulation rates (cm/year)) as a function of ages (cal. BP). For Zones A to E see section "Palaeoenvironmental history". 
the disappearance of the dropstone layers, a lower total sedimentation rate and the slight increase in organic matter in sediments associated with the development of a pioneer tree cover in the catchment, it is unlikely that glacial processes remained active during this period. Whereas hydrological mechanical erosion processes were certainly an important component of the detrital calcium supply because sediments consist almost exclusively of successions of flood layers, chemical weathering probably played an important role. Karst landforms are currently present in conglomerates in the southwestern part of the watershed (Figs. 1B and 2), where metre-deep fissures suggest important water sinking and underground circulation. Moreover, the hypothesis of dissolved calcium inputs released by soil weathering is also plausible since $\mathrm{Ca}$ is one of the first cations mobilized during the early stage of clay alteration (Harnois, 1988). Today, soils cover two-thirds of the catchment, mostly on the smoother slopes, on both marly limestone and conglomerates. Relict soils exhibiting horizon differentiation, notably Podzols, partly cover inherited moraine ridges on the southern side of the lake. On the whole, extension of the tree cover and possibly an early stage of soil formation consecutive to glacier disappearance were the dominant responses of this mountain ecosystem to the early Holocene warming and increasing humidity (Yu and Harrison, 1995; Grafenstein et al., 1999; Larocque and Finsinger, 2008). In the Mediterranean Alps, most lake sediment archives indicate the same final stage of glacial influence at the beginning of the Holocene based on the disappearance of the light-blue clay facies, which is overlain by a beige to light brown silt-clay facies probably comparable to the calcium carbonate-rich facies identified in Lake Allos (e.g. Vallon du Loup Vallon de Provence, Restefond, Sabion (Beaulieu de, 1977), Terres Plaines (Dijkstra et al., 1990), Vei del Bouc (Finsinger, 2001), Lauzanier (Richer, 2009)). The large Durance fluvial system downstream of Lake Allos also attests to a decreased sediment supply at this time (Miramont et al., 2008; Brisset et al., 2014a,b). The general stabilization of slopes was, however, not sufficient to interrupt erosion of the most erodible rock formations in the upper valleys, such as at Allos, that still provided much of the sediment that accumulated.

\subsection{Period C (8600-7200 cal. BP): an environmental prelude to diatom development and forest expansion}

The total sediment accumulation rate decreased to $0.06 \mathrm{~cm} / \mathrm{yr}$ and TOC values increased from 1 to $2 \%$ (Figs. 3 and 4). Distinct sapropelic organic layers, rich in large-sized diatoms, started to be deposited at this time (Fig. 3). Organic sediment accumulation contributed to $50 \%$ of the total accumulation rate. Organic layers were composed of algae, reddish amorphous particles classically derived from humification of plant residues (Meyers and LallierVergès, 1999), and terrestrial plant remains (e.g., wood, leaves, and stomata). This period was characterised by the local expansion of a mixed fir-pine forest. Frequencies of Abies reached $60 \%$ between 7400 and $6600 \mathrm{cal}$. BP, whereas the total tree pollen remained stable at $85 \%$ of the total pollen sum (Fig. 8 ), thus suggesting that fir may have temporarily replaced pine in the lake catchment. The sudden expansion of fir and its transitory dominance in pollen assemblages have been identified in several sites in the Mediterranean Alps (Vei del Bouc (Finsinger, 2001); Vallon de Provence, Vallon du Loup Plan du Laus, Lake Long Inférieur, Lake Mouton, Sabion, Selle di Carnino, Clapeyret (Beaulieu de, 1977); Lake Vens (Brisset et al., 2015)) but the timing has not been as well constrained as at Lake Allos. Besides terrestrial organic matter, a decrease in the $\mathrm{C} / \mathrm{N}$ ratio to 8 suggests that the algal contribution remained predominant compared to terrestrial sedimentation (Meyers and Teranes, 2001). Diatom assemblages were dominated by benthic species (70\% of the total assemblage). The presence, notably of Ellerbeckia arenaria f. teres, which thrives on stones and mosses, and is tolerant to intermittent subaerial exposure, suggests a littoral habitat (Schmid and Crawford, 2001). If we use the maximum water-level range (observed since 1975 AD), a lowering of $13 \mathrm{~m}$ of the lake level will drastically increase the littoral habitat surface, as the depth of the lake in the upper basin falls from 20 to $7 \mathrm{~m}$. Thus, a lowering of the level of Lake Allos might explain the increase in benthic diatoms during this period. Moreover, replacement of biogenic carbonates by biogenic silica is documented by elemental changes (with lower $\mathrm{CaO}$ values and increases in $\mathrm{Al}_{2} \mathrm{O}_{3}$ and $\mathrm{K}_{2} \mathrm{O}$ followed by $\mathrm{SiO}_{2}$ ), although the biogenic contribution in the bulk sediment remained low. This elemental change might also indicate loss of calcium in the detrital fraction, presumably related to pedogenetic processes, i.e., followed by soil acidification. This hypothesis, which has also been proposed for this period in Lake Anterne in the northern Alps by Giguet-Covex et al. (2011), matches well with the development of diatoms boosted by this change in nutrient supply, as has been shown in the Lake Petit record not far from Lake Allos (Brisset et al., 2012, 2013; Cartier et al., 2015). Soil acidification and long-term cation release may have also induced a lowering of lake water $\mathrm{pH}$, an important limiting factor for calcification reaction (Marubini and Atkinson, 1999), thus preventing ostracod development.

Slopes were protected from erosion by dense conifer forests which probably favoured the formation of acid soils, fertilising the lake in dissolved cation and organic matter, and probably modifying the $\mathrm{pH}$ of the lake water, and, altogether triggering a shift in aquatic communities. The other high-altitude sites of the Mediterranean Alps appear to evince the same evolution pattern, even though the interpretations are based solely on sedimentological descriptions. This period is always characterised by the deposition of dark algae-dominated sediments (e.g. Lake Sabion, Vallon de Provence and Vallon du Loup (Beaulieu de, 1977), Lake Grenouilles (Kharbouch, 2000), Lake Long Inférieur (Ponel et al., 2001), Vei del Bouc (Finsinger, 2001), Orgials and Rifugio Mondovi (Ortu, 2002), Lake Lauzanier (Richer, 2009), Lake Petit (Brisset et al., 2013), and Lake Vens (Brisset et al., 2015)). Finally, the stabilization of highaltitude catchments has also been synchronous with the disappearance of mid-altitude torrents in the Mediterranean Alps (Brisset et al., 2014a,b).

\subsection{Period D (7200-3000 cal. BP): an optimum for ecosystems?}

The total accumulation rate over this period remained low $(0.1 \mathrm{~cm} /$ year $)$, and was characterised by the deposition of thick organic layers, whereas occurrences of flood layers were rare (Brisset et al., 2017). Organic carbon abundance reached its highest values $(2.2 \%)$ and $\mathrm{C} / \mathrm{N}$ dropped to a minimum $(<8)$, thus suggesting that lacustrine sedimentation was dominated by algal production. The mean diatom concentrations were high (5000 valves $/ \mathrm{cm}^{3}$ ), mainly represented by $P$. bodanica var. lemanica; E. arenaria $f$. teres, whereas ostracods totally disappeared. This period was also characterised by minimal values of $\mathrm{CaO}$ (nearly zero). Following interpretations in the previous paragraphs, it may be assumed that soil decalcification processes were achieved during this period, which implies that soils were well-developed in the watershed. Following $6500 \mathrm{cal}$. BP, tree pollen percentages remained still high, and replacement of fir by pine and larch occurred. This modification of the forest composition, which implied the development of open pine/larch forests close to the lake, is also associated with the first occurrence of Urtica in the pollen record, a plant having strong affinities for nutrient-rich soils generally favoured by livestock grazing (Behre, 1981; Court-Picon, 2007). The same vegetation dynamic is observed in other pollen records from the Mediterranean Alps (e.g. Lake Long Inférieur (Ponel et al., 2001), Lake Vens 
(Brisset et al., 2015)), an argument in favour of the presence of domestic livestock at these altitudes by that time. Even though there are no archaeological excavations in Lake Allos catchment, archaeological studies in the Ecrins and Champsaur massifs ( $60 \mathrm{~km}$ north of Lake Allos) attest to human frequentation of the high-altitude valleys from the Late Mesolithic onwards (Walsh et al., 2007; Mocci et al., 2008), but without any evidence of pastoral activities. The oldest circular enclosure characteristic of pastoral activities has been dated at 6000-5000 cal. BP (Mocci et al., 2008). Obviously, the earliest evidence of human activity in these environments is still difficult to access. Thus, the commonly accepted interpretation is that the first appearance of Urtica pollen attests, a minima, to the transhumance routes of the earliest pastoralists, from perennial occupation of the lowlands to seasonal migration to high-altitude sites (Walsh et al., 2014; Battentier et al., in press; Walsh and Mocci, 2016). Besides, starting from the Late Neolithic and during the Bronze Age (from 4000 to 2500 cal. BP), the increasing number of artifacts dedicated to pastoral purposes fits well with the abundance of ruderal-anthropogenic grasses, and Urtica in particular (Walsh et al., 2014), thus suggesting that these environments comprised cultivated meadows and pastures.

Altogether, these results suggest that sediments on slopes were stabilized during this period through long-term expansion of the forest cover and soil formation in the catchment, feeding the lacustrine biota in nutrients, and notably silica that promoted diatom production. Moreover, even if a shift from a denser to a more open forest occurred in response to discrete human impact, this change did not modify the long-lasting dynamic of soil development and sediment fixing on slopes. This probably explains why no significant disturbance affected diatom growth. At Lake Long Inférieur, Gandouin and Franquet (2002) showed that thermophilous chironomid taxa, such as Dicrotendipes, Polypedilum and Microtendipes, were indicative of higher lake trophic levels at that period, following vegetation evolution.

A closer scrutiny of the period from 4500 cal. BP to 3000 cal. BP shows that the total sedimentation rate started to increase, bounded at $80 \%$ by the organic accumulation rate (Fig. 8). Largeamplitude shifts from benthic (E. arenaria $f$. teres) to planktonic diatom species (e.g., P. bodanica var. lemanica) characterised this period (Fig. 6). In cases of lakes having a relatively simple morphology (one deep basin), benthic diatom abundances are likely to decrease with increasing lake level (Stone and Fritz, 2004); thus, rapid changes in benthic/planktonic species at Allos may have been linked to lake-level variations. During this time, the catchment landscape did not undergo any noteworthy modification. Thus, changes in diatom assemblages may not have been linked to vegetation or detrital supply, suggesting that diatoms were more directly linked to climate change affecting the lake level. According to Digerfeldt et al. (1997), there was a moderate rise in lake level at Saint-Léger (1300 m a.s.l) from 4500 to 4000 cal. BP, subsequently followed by a lowering that culminated at $3300 \mathrm{cal}$. BP. At the same altitude as Lake Allos, Lake Petit (2200 $\mathrm{m}$ a.s.l) shows a record with major changes in precipitation regime around 4200 cal. BP, resulting in a regime shift in diatom assemblages (Brisset et al., 2013; Cartier et al., 2015).

\subsection{Period E (3000 cal. BP to present-day): an overall degradation} of the environment

An important increase in total accumulation rate (up to $0.3 \mathrm{~cm} /$ year) occurred because of increasing detrital inputs. Laminae are composed of thicker and more frequent coarse mineral deposits transported during flood episodes (Brisset et al., 2017). Increased detrital carbonate inputs are correlative with a decrease in TOC and tree pollen (Fig. 8). In the lake, E. arenaria $f$. teres disappeared, whereas small-sized planktonic species (Cyclotella comensis and C. rosii) well adapted to deep waters with enhanced water column stratification developed (Winder et al., 2009). On slopes, increasing grass pollen percentages and the continuous occurrence of Urtica suggest the presence of domestic livestock and grassland in the close vicinity of the lake (Fig. 8), in agreement with the continuous record of pastoral artifacts in high-altitude environments in the Southern Alps during the Late Bronze Age (Mocci et al., 2008). This more open landscape is concomitant with an increase in eutrophic diatoms ( $P$. radiosa, G. acuminatum, S. medius) and the appearance of a new ostracod species Cypria ophthalmica, suggesting enrichment of the lake waters. The supply of nutrients, and nitrogen in particular, may have originated from soils on which nitrophilous plants had gradually developed.

From $1700 \mathrm{cal}$. BP at Allos, the development of alpine meadows (Rumex, Chenopodiaceae, Urtica, Plantago lanceolata) attests undoubtedly to a strong impact of pastoral activities on vegetation. Moreover, the transitory increase in Caryophyllaceae observed at that time (PAZ6 Fig. 5) could be interpreted as an expansion of grazed meadows. From this time on, diatom concentrations in the sediments are very variable due to a high dilution with detrital particles from flood deposits. P. bodanica var. lemanica disappears whereas $C$. comensis and $C$. rosii remain abundant. Eutrophic diatoms increase again (e.g., P. radiosa, G. acuminatum) together with the ostracod species Cypria ophthalmica. In contrast to the Bronze Age period, only very few pastoral structures corresponding to the Roman period and restricted to mid-altitude positions along the transalpine roads have been discovered (Mocci et al., 2010). This period corresponded to a change in land use at lower altitudes, as confirmed by the presence of Olea and Juglans in the pollen record (Fig. 5).

Finally, two levels of sapropelic black organic sediments are intercalated within the dominant detrital sedimentation. The first level (from 1000 to $700 \mathrm{cal}$. BP) is characterised by an increase in TOC and TS (Fig. 4), suggesting high organic production and poor deep-water oxygenation. The closest diatom sample (1300 cal. BP) shows an assemblage typical of a nearby littoral environment rich in aquatic vegetation (Gomphonema sp.) (Fig. 6). These changes in the lake ecosystem might have been the result of warming during the Middle Ages (Medieval Climatic Optimum; Wilhelm et al., 2012), and/or a consequence of increasing grazing pressure. Indeed, archaeological studies have documented a recrudescence of extensive agro-pastoralism in high altitudes from the Late Antiquity $(\sim 1400-1000 \mathrm{cal}$. BP) that intensified during the Middle Ages (Walsh et al., 2007). The second level covering the last century (high TOC and $\mathrm{P}_{2} \mathrm{O}_{5}$ (Fig. 4)) is correlative with a sudden change in diatom levels (increase of C. cyclopuncta, F. ulna var. acus, S. medius) and in chironomid assemblages (Giguet-Covex et al., 2014), indicating both nutrient enrichment of waters and decrease in oxygenation at the sediment/water interface. Ecosystem disturbances over this period could be attributed mainly to leisure activities (tourism) and to wastewaters from the Allos mountain refuge built in $1904 \mathrm{AD}$, given the declining sizes of herds in the watershed (Etienne et al., 2013).

\subsection{Synchronicity and divergence of ecosystem trajectories}

The Holocene is traditionally described in the palaeoenvironmental literature as a tripartite epoch composed of "Early", "Mid" (or Middle) and "Late" phases. To render the Holocene stratigraphic terminology more consistent, Walker et al. (2012) proposed an Early-Middle Holocene boundary at $8200 \mathrm{cal}$. $\mathrm{BP}$ and a Middle-Late Holocene boundary at $4200 \mathrm{cal}$. BP (Mayewski et al., 2004). These limits were based on two climatic events that led to important changes in oceanic or atmospheric 
global circulation (Alley et al., 2003; Pross et al., 2009). However, these subdivisions are not recorded in all sites and, more importantly, the timing of environmental responses has not always been synchronous at a large scale (Wischnewski et al., 2011).

At Allos, two main transitions in the environmental history can be identified for all environmental compartments, respectively at 8600 and 3000 cal. BP:

- at 8600 cal. BP, a decrease in detrital sediment supply (related to soil development with lower $\mathrm{CaO}$ values) as dense conifer forests developed in the catchment, and a change in water physicochemistry, favoured the proliferation of diatoms (at the expense of calcified organisms). This phase has been previously related to a long-lasting maturation of the watershed favoured by the general climate amelioration during the Early/Mid-Holocene;

- at 3000 cal. BP, the detrital supply increased, while forests became more open and nutrient-rich alpine meadows developed because of increasing anthropogenic disturbances. Calcified organisms in the lake reappeared, while planktonic and eutrophic diatoms developed. These changes correspond to the end of a phase of relative stability of slopes and of ecosystems at Allos corresponding to the end of the Mid-Holocene phase.

However, despite the similar long-term trajectory (explained by the very close relationships between the watershed and the lake), divergence between the geosystem compartments occurred between 4500 and $3000 \mathrm{cal}$. BP, when the behaviour of the aquatic compartment no longer corresponded to proxies related to catchment processes. This phase was characterised by a maximum in algal production, bounded almost exclusively by large-amplitude oscillations in benthic diatom frequency ( $E$. arenaria abundances ranged between 20 and $\sim 100 \%$ ). This high variability in diatom assemblages cannot be explained by any change in erosive dynamics or in vegetation (the main drivers of nutrient supply to the lake). This variability suggests a major role played by an external driver on lake functioning, namely high-frequency variability of the lake's water balance, involving frequent switches in lake level from high to low, and vice versa. This period corresponds to the $4200 \mathrm{cal}$. BP climatic event, which has been identified in numerous records in the Northern Hemisphere (Mayewski et al., 2004), and which has been characterised in the Mediterranean region as an abrupt, centennial-scale, drier oscillation (Drysdale et al., 2006; Weiss, 2015) associated with high variability in lake levels (Magny et al., 2007, 2009) and with erosive crises (Brisset et al., 2013).

This divergence between terrestrial and aquatic ecosystems might be a result of different sensitivities to external forcing (Battarbee, 2000; Wischnewski et al., 2011). Indeed, ecosystem responses can be delayed, buffered, or amplified, depending on the resistance and plasticity of the considered compartment (Grime et al., 2000; Richter et al., 2012; Brisset et al., 2013; Cartier et al., 2015; Hoffmann, 2015). Moreover, long-term changes in soil properties and/or human activities can play a major role in vegetation successions through chemical weathering and mechanical erosion. On the other hand, lake morphologies and the proximity of alpine lakes to climatically sensitive thresholds (ice-cover, thermal stratification, and hydrological balance) could amplify climatic signals in aquatic systems (Battarbee, 2000).

From a theoretical point of view, the multiproxy study of Lake Allos highlights the possibility that development divergence can occur in compartments of the same geosystem, notwithstanding the fact that they are subjected to common forcing factors. In this context, if major environmental changes need to be identified in all proxies, two transitions would be defined at Allos (8600 and $3000 \mathrm{cal}$. BP). However, this partitioning of the environmental history is highly dependent on the sensitivity, the geographical location and the local properties of the watershed. Thus, a choice of intra-Holocene stratigraphical boundaries common to all ecosystem compartments (and all study sites) is not convenient as it could mask the complexity of ecosystem adjustment to external forcing and would not correspond to homogenous periods of ecosystem functioning. Moreover, as suggested previously by Birks and Birks (2006), this can also lead to confirmatory approaches following which data interpretation could be 'forced' to fit into a particular global stratigraphical partitioning. Between sites, the comparison may be even more difficult as environmental changes are not only driven by natural forces but also by human influence (Roberts et al., 2011). As land use and settlement practices have varied in time and space, interaction with climate forcing can induce disparities between regions (Kalis et al., 2003; Hoffmann et al., 2010).

Finally, according to these results, the Allos record underscores the fact that Lateglacial to Holocene palaeoenvironmental history should be viewed more in terms of progressive and transient changes rather than abrupt and net limits in the evolution of the geosystem and, that climatic events (particularly those of short duration), do not affect all ecological compartments through the same processes, nor with the same intensity. This again underlines the importance of a multi-compartment approach.

\section{Conclusions}

The purpose of this paper has been to reconstruct biotic and abiotic interactions in an alpine geosystem since the deglaciation, by improving our understanding of similarities and divergences in evolution trajectories between diverse compartments of mountain landscapes (i.e., vegetation, soils, lacustrine environment) facing external forcing. Our multiproxy study has enabled accurate reconstruction of the close links between lake communities and vegetation and erosion processes over the last 14,000 years, providing, for the first time, a well-constrained palaeoenvironmental record for the Southern Alps for this period. The study has revealed five main periods in the environmental history of this region:

- from 13,500 to $\sim 12,000$ cal. BP: a preponderance of glaciofluvial processes during the first stages of lake establishment consecutive to glacier retreat at elevations above $2230 \mathrm{~m}$ a.s.l. The detrital supply was high, while slopes were rather poorly protected from erosion by steppe vegetation;

- from 12,000-8600 cal. BP: an extension of the tree cover associated with soil formation and karst-forming processes (chemical weathering), leading to an important development of ostracods in the lake. Coarse detrital supply was still high over this period, indicating that catchment slopes were not yet completely stabilized;

- from 8600 to 7200 cal. BP: a progressive decline in calcium inputs and ostracods in the lake together with an increase in TOC and a development of fir/pine forest highlight a gradual transition in the lake and in the terrestrial ecosystem;

- From 7200 to 3000 cal. BP: a strong connectivity between the geosystem compartments followed by an increase in aquatic biogenic production. The detrital supply was low and mainly composed of aluminosilicate elements while a dense mixed fir/pine forest developed on slopes (rapidly replaced by larches). The change in element supply from calciumdominated to silica associated with more organic matter led to an optimum for diatom growth and disappearance of ostracods;

- from 3000 cal. BP to Present: an increase in geosystem disturbance related to human activities. A rebound in detrital 
inputs related to a reduction of the tree cover, and a development of alpine meadows, resulted in an increase in eutrophic aquatic species.

Two main environmental transitions were recorded in all geosystem compartments at 8600 and $3000 \mathrm{cal}$. BP, framing a midHolocene period at Allos. Moreover, the period from 4500 to 3000 cal. BP stands out clearly because major changes occurred only in the lake ecosystem, thus translating the direct influence of climate forcing during the $4.2 \mathrm{ka}$ climatic event on the hydrological balance. This study highlights the difficulty of defining common intra-Holocene stratigraphical boundaries because compartments of any one geosystem are likely to have inherently different responses to common forcing factors. Additionally, intra-Holocene environmental boundaries at Allos correspond more to progressive changes rather than clear temporal limits. Finally, this multiproxy approach has revealed the fact that the inherited history of a geosystem and the long-term interactions between ecological compartments determine the type of environmental responses to the external forcing. In this context, the capacity of an ecosystem to accommodate disturbances (climate change, land-use changes) and to retain its structure depends on the particular history of its watershed. Keeping these long-term trends in mind, it will then be possible to move towards better ecological protection without expecting a return neither to pristine environmental conditions that may no longer exist today, nor, in a matter of years, to what takes millennia in natural conditions.

\section{Funding}

This study was funded by the Programme d'Intérêt Transfrontalier (Parc National du Mercantour, France) led by F. Suméra (SRA-PACA) entitled "Etude de l'usage et de l'occupation Du sol et du territoire Mercantour", and by the project LADICIA, "quand l'homme et le climat faconnent la montagne meridionale: le Lac d'Allos, une histoire du Détritisme, des Instabilités Climatiques et des Impacts Anthropiques" (Région PACA, ref. 2010_08_012) led by C. Miramont (IMBE). R. Cartier and E. Brisset benefited, respectively, from PhD grants from the French Ministry of Education and Région PACA.

\section{Acknowledgments}

Coring of Lake Allos was rendered possible thanks to F. Arnaud, E. Malet, P. Sabatier (EDYTEM) and Chrono-Environnement. We thank E. Dambrine (INRA-Savoie University) for help in soil determination and discussions. We are grateful to F. Ruaudel (IMBE) for CNS analyses and to A. Tonetto for the SEM expertise (Aix-Marseille University).

\section{Appendix A. Supplementary data}

Supplementary data related to this article can be found at https://doi.org/10.1016/j.quascirev.2018.02.016.

\section{References}

Adrian, R., O'Reilly, C.M., Zagarese, H., Baines, S.B., Hessen, D.O., Keller, W. Livingstone, D.M., Sommaruga, R., Straile, D., Van Donk, E., Weyhenmeyer, G.A., Winder, M., 2009. Lakes as sentinels of climate change. Limnol. Oceanogr. 54, 2283-2297.

Agence de l'eau Rhône Méditerranée Corse, 2013. Etude des plans d'eau du programme de surveillance des bassins Rhône Méditerranée et Corse - rapport de données brutes et interprétation Lac d'Allos. Suivi annuel. 83 pp.

Alley, R.B., Marotzke, J., Nordhaus, W.D., Overpeck, J.T., Peteet, D.M., Pielke, R.A., Pierrehumbert, R.T., Rhines, P.B., Stocker, T.F., Talley, L.D., Wallace, J.M., 2003. Abrupt climate change. Science 299, 2005-2010.
Arnaud, F., Lignier, V., Revel, M., Desmet, M., Beck, C., Pourchet, M., Charlet, F., Trentesaux, A., Tribovillard, N., 2002. Flood and earthquake disturbance of 210Pb geochronology (Lake Anterne, NW Alps). Terra. Nova 14, 225-232.

Bajard, M., Poulenard, J., Sabatier, P., Etienne, D., Ficetola, F., Chen, W., Gielly, L., Taberlet, P., Develle, A.-L., Rey, P.-J., Moulin, B., de Beaulieu, J.-L., Arnaud, F., 2017. Long-term changes in alpine pedogenetic processes: effect of millennial agropastoralism activities (French-Italian Alps). Geoderma 306, 217-236.

Battarbee, R.W., 2000. Palaeolimnological approaches to climate change, with special regard to the biological record. Quat. Sci. Rev. 19 (1), 107-124.

J. Battentier, D. Binder, S. Guillon, R. Maggi, F. Negrino, I. Sénépart, C. Tozzi, I. ThéryParisot, C. Delhon, The environment of the last hunters-gatherers and first agropastoralists in the western Mediterranean region, between the Rhone and the Northern Apennines (7th - 6th millennium cal. BCE): attractiveness of the landscape units and settlement patterns, Quat. Sci. Rev., in press, Available online 23 August 2017.

de Beaulieu, J.L., 1977. Contribution pollenanalytique à l'histoire tardiglaciaire et holocène de la végétation des Alpes méridionales françaises. PhD thesis. AixMarseille Univ.. p.358.

Behre, K.-E., 1981. The interpretation of anthropogenic indicators in pollen diagrams. Pollen Spores 23, 225-245.

Bennett, K.D., 1996. Determination of the number of zones in a biostratigraphical sequence. New Phytol. 132, 155-170.

Bennion, H., Battarbee, R.W., Sayer, C.D., Simpson, G.L., Davidson, T.A., 2011. Defining reference conditions and restoration targets for lake ecosystems using palaeolimnology: a synthesis. J. Paleolimnol. 45, 533-544.

Birks, H.H., Birks, H.J.B., 2006. Multi-proxy studies in palaeolimnology. Veg. Hist. Archaeobot. 15, 235-251.

Blaauw, M., 2010. Methods and code for "classical" age-modelling of radiocarbon sequences. Quat. Geochronol. 5, 512-518.

Blockley, S.P.E., Lane, C.S., Hardiman, M., Rasmussen, S.O., Seierstad, I.K., Steffensen, J.P., Svensson, A., Lotter, A.F., Turney, C.S.M., Bronk Ramsey, C., 2012. Synchronisation of palaeoenvironmental records over the last 60,000 years, and an extended INTIMATE1 event stratigraphy to 48,000 b2k. Quat. Sci. Rev. 36, $2-10$.

Böning, P., Bard, E., Rose, J., 2007. Toward direct, micron-scale XRF elemental maps and quantitative profiles of wet marine sediments. Geochem. Geophys. Geosys.

Boudevillan, B., Argence, S., Claud, C., Ducrocq, V., et al., 2009. Cyclogénèses et précipitations intenses en région méditerranéenne : origines et caractéristiques. Meteorol 66, 18-28.

Brauer, A., Casanova, J., 2001. Chronology and depositional processes of the laminated sediment record from Lac d'Annecy, French Alps. J. Paleolimnol. 25, 163-177.

Brisset, E., Guiter, F., Miramont, C., Delhon, C., Arnaud, F., Disnar, J.-R., Poulenard, J. Anthony, E., Meunier, J.-D., Wilhelm, B., Pailles, C., 2012. Approche multidisciplinaire d'une séquence lacustre holocène dans les alpes du sud au Lac Petit (Mercantour, alt. 2200 m, France): histoire d'un géosystème dégradé. Quaternaire 23, 309-319.

Brisset, E., Miramont, C., Guiter, F., Anthony, E.J., Tachikawa, K., Poulenard, J., et al., 2013. Non-reversible geosystem destabilisation at 4200 cal. BP: sedimentological, geochemical and botanical markers of soil erosion recorded in a Mediterranean alpine lake. Holocene 23 (12), 1863-1874.

Brisset, E., Miramont, C., Guiter, F., Arnaud, F., Anthony, E., Delhon, C., Guibal, F., Cartier, R., Poher, Y., Chaumillon, E., 2014a. Données nouvelles sur la chronologie de la déglaciation dans la vallée du Haut-Verdon (lac d'Allos, Alpes françaises du Sud). Quaternaire 25 (2), 147-156.

Brisset, E., Miramont, C., Anthony, E.J., Bruneton, H., Rosique, T., Sivan, O., 2014b. Sediment budget quantification of a sub-Alpine river catchment since the end of the last glaciation. CATENA 114, 169-179.

Brisset, E., Guiter, F., Miramont, C., Revel, M., Anthony, E.J., Delhon, C., Arnaud, F., Malet, E., de Beaulieu, J.-L., 2015. Lateglacial/Holocene environmental changes in the Mediterranean Alps inferred from lacustrine sediments. Quat. Sci. Rev. 110, 49-71.

Brisset, E., Guiter, F., Miramont, C., Troussier, T., Sabatier, P., Poher, Y., Cartier, R., Arnaud, F., Malet, E., Anthony, E.J., 2017. The overlooked human influence in historic and prehistoric floods in the European Alps. Geology 45 (4), 347-350.

Buzzi, A., Foschini, L., 2000. Mesoscale meteorological features associated with heavy precipitation in the southern alpine region. Meteorol. Atmos. Phys. 72, 131-146.

Cannone, N., Sgorbati, S., Guglielmin, M., 2007. Unexpected impacts of climate change on alpine vegetation. Front. Ecol. Environ. 5, 360-364.

Caporaletti, M. 2011. Ostracods and stable isotopes: proxies for palaeoenvironmental reconstructions. J. Geol. Paläontol. 11, 345-359.

Carignan, J., Hild, P., Mevelle, G., Morel, J., Yeghicheyan, D., 2001. Routine analyses of trace elements in geological samples using flow injection and low pressure online liquid chromatography coupled to ICP-MS: a study of geochemical reference materials BR, DR-N, UB-N, AN-g and GH. Geostand. Newsl. 25, 187-198.

Cartier, R., Brisset, E., Paillès, C., Guiter, F., Sylvestre, F., Ruaudel, F., Anthony, E.J., Miramont, C., 2015. 5000 years of lacustrine ecosystem changes from Lake Petit (Southern Alps, $2200 \mathrm{~m}$ asl): regime shift and resilience of algal communities. Holocene 25, 1231-1245.

Court-Picon, M., 2007. Mise en place du paysage dans un milieu de moyenne et haute montagne du tardiglaciaire à l'époque actuelle : analyse du signal palynologique en Champsaur (Hautes-Alpes, France) à l'interface des dynamiques naturelles et des dynamiques sociales. PhD thesis. Univ. de Franche-Comté, 732 
pp.

Cuven, S., Francus, P., Lamoureux, S.F., 2010. Estimation of grain size variability with micro X-ray fluorescence in laminated lacustrine sediments, Cape Bounty, Canadian High Arctic. J. Paleolimnol. 44, 803-817. https://doi.org/10.1007/s10933010-9453-1.

Czymzik, M., Brauer, A., Dulski, P., Plessen, B., Naumann, R., von Grafenstein, U., Scheffler, R., 2013. Orbital and solar forcing of shifts in Mid- to Late Holocene flood intensity from varved sediments of pre-alpine Lake Ammersee (southern Germany). Quat. Sci. Rev. 61, 96-110.

Dam, H.V., Mertens, A., Sinkeldam, J., 1994. A coded checklist and ecological indicator values of freshwater diatoms from The Netherlands. Neth. J. Aquat. Ecol. $28,117-133$.

Digerfeldt, G., de Beaulieu, J.-L., Guiot, J., Mouthon, J., 1997. Reconstruction and paleoclimatic interpretation of Holocene lake-level changes in Lac de SaintLéger, Haute-Provence, southeast France. Palaeogeogr. Palaeoclimatol. Palaeoecol. 136, 231-258.

Dijkstra, T.A., Janssen, C.R., Middelkoop, H., Salomé, A.I., 1990. Observations concerning the extent and chronology of the Late-Glacial déglaciation stages in the Southern French Alps on the basis of two pollen diagrams. Quaternaire 1, 123-137.

Douguedroit, A., 1976. Les paysages forestiers de haute-provence et des alpes maritimes : geographie, ecologie, histoire. EDISUD Aix-en-provence, 550 pp.

Drysdale, R., Zanchetta, G., Hellstrom, J., Maas, R., Fallick, A., Pickett, M., Cartwright, I., Piccini, L., 2006. Late Holocene drought responsible for the collapse of Old World civilizations is recorded in an Italian cave flowstone. Geology 34, 101-104.

Etienne, D., Wilhelm, B., Sabatier, P., Reyss, J.-L., Arnaud, F., 2013. Influence of sample location and livestock numbers on Sporormiella concentrations and accumulation rates in surface sediments of Lake Allos, French Alps. J. Paleolimnol. 49, 117-127.

Faegri, K., Iversen, J., 1989. Textbook of Pollen Analysis, 4e edition. Wiley \& Sons, New York. 328 pp.

Federici, P.R., Stefanini, M.C., 2001. Evidences and chronology of the little ice age in the argentera massif (Italian Maritime Alps). Z. Gletscherkd. Glazialgeol. 37, 35-48.

Finsinger, W., 2001. Vegetation history and human impact at the Lago del Vei del Bouc (Argentera Massif, Maritime Alps)/Histoire de la végétation et de l'impact de l'homme au Lago del Vei del Bouc (Massif de l'Argentera, Alpes-Maritimes). Quaternaire 12, 223-233.

Gandouin, E., Franquet, E., 2002. Late Glacial and Holocene chironomid assemblages in Lac Long Inférieur (southern France, $2090 \mathrm{~m}$ ): palaeoenvironmental and palaeoclimatic implications. J. Paleolimnol. 28, 317-328.

Giguet-Covex, C., Arnaud, F., Poulenard, J., Disnar, J.-R., Delhon, C., Francus, P., David, F., Enters, D., Rey, P.-J., Delannoy, J.-J., 2011. Changes in erosion patterns during the Holocene in a currently treeless subalpine catchment inferred from lake sediment geochemistry (Lake Anterne, 2063 m a.s.l., NW French Alps): the role of climate and human activities. Holocene 21, 651-665.

Giguet-Covex, C., Pansu, J., Arnaud, F., Rey, P.-J., Griggo, C., Gielly, L., Domaizon, I., Coissac, E., David, F., Choler, P., Poulenard, J., Taberlet, P., 2014. Long livestock farming history and human landscape shaping revealed by lake sediment DNA. Nat. Commun. 5 article number 3211.

Gobet, E., Tinner, W., Hochuli, P.A., Leeuwen, J.F.N., van, Ammann, B., 2003. Middle to late Holocene vegetation history of the upper engadine (Swiss Alps): the role of man and fire. Veget Hist Archaeobot 12, 143-163.

Gobiet, A., Kotlarski, S., Beniston, M., Heinrich, G., Rajczak, J., Stoffel, M., 2014. 21st century climate change in the European Alps-a review. Sci. Total Environ. 493, 1138-1151.

Grafenstein, U., Helmut Erlenkeuser, H., Brauer, A., Jouzel, J., Johnsen, S.J., 1999. A mid-european decadal isotope-climate record from 15,500 Years B.P. Science 284, 1654-1657.

Grime, J.P., Brown, V.K., Thompson, K., Masters, G.J., Hillier, S.H., Clarke, I.P., Askew, A.P. Corker, D., Kielty, J.P., 2000. The response of two contrasting limestone grasslands to simulated climate change. Science 289, 762-765.

Grimm, E.C., 1987. CONISS: a FORTRAN 77 program for stratigraphically constrained cluster analysis by the method of incremental sum of squares. Comput. Geosci. $13,13-35$

Harnois, L., 1988. The CIW index: a new chemical index of weathering. Sediment. Geol. 55 (3-4), 319-322.

Harsh, M.A., Hulme, P.E., McGlone, M.S., Duncan, R.P., 2009. Are treeline advancing? A global meta-analysis of treeline response to climate warming. Ecol. Lett. 12 (issue 10), 1040-1049.

Hausmann, S., Lotter, A.F., 2001. Morphological variation within the diatom taxon Cyclotella comensis and its importance for quantitative temperature reconstructions. Freshw. Biol. 46, 1323-1333.

Heinrich, G., Gobiet, A., 2012. The future of dry and wet spells in Europe: a comprehensive study based on the ENSEMBLES regional climate models. Int. J. Climatol. 32, 1951-1970.

Heiri, O., Lotter, A.F., 2003. 9000 years of chironomid assemblage dynamics in an Alpine lake: long-term trends, sensitivity to disturbance, and resilience of the fauna. J. Paleolimnol. 30, 273-289.

Hilderbrand, R., Watts, A., Randle, A., 2005. The myths of restoration ecology. Ecol. Soc. $10(1), 19$.

Hoffmann, T., 2015. Sediment residence time and connectivity in non-equilibrium and transient geomorphic systems. Earth Sci. Rev. 150, 609-627.

Hoffmann, T., Thorndycraft, V.R., Brown, A.G., Coulthard, T.J., Damnati, B., Kale, V.S.,
Middelkoop, H., Notebaert, B., Walling, D.E., 2010. Human impact on fluvial regimes and sediment flux during the Holocene: review and future research genda. Global Planet. Change 72, 87-98.

Jorda, M., 1975. Les montagnes du Haut Verdon, Etude géomorphologique. Méditerranée 20, 37-58.

Juggins, S., 2012. C2 Version 1.5, User Guide. Software for Ecological and Palaeoecological Data Analysis and Visualisation. Newcastle Univ., 77 pp.

Kalis, A.J., Merkt, J., Wunderlich, J., 2003. Environmental changes during the Holocene climatic optimum in central Europe - human impact and natural causes. Quat. Sci. Rev. 22, 33-79.

Kharbouch, M., 2000. L'homme et la végétation dans la région du mont Bego Tende, Alpes-Maritimes) depuis des millénaires. Comptes Rendus Acad. Sci. Ser. IIA Earth Planet. Sci. 330, 889-894.

Körner, C., 1995. Alpine plant diversity: a global survey and functional in terpretations. In: III, P.D.F.S.C., Körner, P.D.C. (Ed.), Arctic and Alpine Biodiversity: Patterns, Causes and Ecosystem Consequences, Ecological Studies. Springer, Berlin Heidelberg, pp. 45-62.

Krammer, K., Lange-Bertalot, H., 1986-1991. Bacillariophyceae. Süsswasserflora von Mitteleuropa, 2/1-2/4. G. Fischer Verlag, Stuttgart.

Lampert, W., Sommer, U., 2007. Limnoecology: the Ecology of Lakes and Streams, second ed. Oxford University Press. 324 pp.

Larocque, I., Finsinger, W., 2008. Late-glacial chironomid-based temperature reconstructions for Lago Piccolo di Avigliana in the southwestern Alps (Italy). Palaeogeogr. Palaeoclimatol. Palaeoecol. 257, 207-223.

Livingstone, S.J., Piotrowski, J.A., Bateman, M.D., Ely, J.C., Clark, C.D., 2015 Discriminating between subglacial and proglacial lake sediments: an example from the Dänischer Wohld Peninsula, northern Germany. Quat. Sci. Rev. 112, 86-108.

Lotter, A.F., Birks, H.J.B., 2003. The Holocene palaeolimnology of Sägistalsee and its environmental history - a synthesis. J. Paleolimnol. 30, 333-342.

Lotter, A.F., Heiri, O., Hofmann, W., Knaap, W.O., van der, Leeuwen, J.F.N., van, Walker, I.R., Wick, L., 2006. Holocene timber-line dynamics at Bachalpsee, a lake at $2265 \mathrm{~m}$ a.s.l. in the northern Swiss Alps. Veget Hist Archaeobot 15, 295-307.

Macias-Fauria, M., Johnson, E.A., 2013. Warming-induced upslope advance of subalpine forest is severely limited by geomorphic processes. Proc. Natl. Acad. Sci. Unit. States Am. 110, 8117-8122.

Magny, M., de Beaulieu, J-L, Drescher-Schneider, R. Vannière, B., WalterSimonnet, A.-V., Miras, Y., Millet, L., Bossuet, G., Peyron, O., Brugiapaglia, E. Leroux, A., 2007. Holocene climate changes in the central Mediterranean as recorded by lake-level fluctuations at Lake Accesa (Tuscany, Italy). Quat. Sci. Rev. 26, 1736-1758.

Magny, M., Vannière, B., Zanchetta, G., Fouache, E., Touchais, G., Petrika, L. Coussot, C., Walter-Simonnet, A.-V., Arnaud, F., 2009. Possible complexity of the climatic event around 4300-3800 cal. BP in the central and western Mediterranean. Holocene 19,823-833.

Magny, M., Combourieu-Nebout, N., de Beaulieu, J.L., Bout-Roumazeilles, V. Colombaroli, D., et al., 2013. North-south palaeohydrological contrasts in the central Mediterranean during the Holocene: tentative synthesis and working hypotheses. Clim. Past 9, 2043-2071.

Mangerud, J., Andersen, S.T., Berglund, B.E., Donner, J.J., 1974. Quaternary stratigraphy of Norden, a proposal for terminology and classification. Boreas 3, 109-126.

Marubini, F., Atkinson, M.J., 1999. Effects of lowered pH and elevated nitrate on coral calcification. Mar. Ecol. Prog. Ser. 188, 117-121.

Mayewski, P.A., Rohling, E.E., Curt Stager, J., Karlén, W., Maasch, K.A., David Meeker, L., Meyerson, E.A., Gasse, F., van Kreveld, S., Holmgren, K., Lee-Thorp, J. Rosqvist, G., Rack, F., Staubwasser, M., Schneider, R.R., Steig, E.J., 2004. Holocene climate variability. Quat. Res. 62, 243-255.

Meisch, C., 2000. Freshwater Ostracoda of Western and Central Europe. Spektrum Akademischer Verlag GmbH, Heidelberg, Berlin, 522 pp.

Meyers, P.A., Lallier-Vergès, E., 1999. Lacustrine sedimentary organic matter records of Late Quaternary paleoclimates. J. Paleolimnol. 21, 345-372.

Meyers, P.A., Teranes, J.L., 2001. Sediment organic matter. In: Last, W.M., Smol, J.P. (Eds.), Tracking Environmental Change Using Lake Sediments, vol. 2. Springer, Netherlands, pp. 239-269. Physical and Geochemical methods.

Mezquita, F. Roca, J.R., Wansard, G., 1999. Moulting, survival and calcification: the effects of temperature and water chemistry on an ostracod crustaceac (Herpetocypris intermedia) under experimental conditions. Arch. Hydrobiol. 146 219-238.

Miramont, C., Boutterin, C., Sivan, O., Bruneton, H., Mantran, M., 2008. Grandes séquences et principales ruptures morphogéniques en Haute Provence - les complexes sédimentaires des petits organismes torrentiels de moyenne Durance. Cahiers de Paléoenvironnement, 6. EDYTEM, pp. 145-154.

Mocci, F., Walsh, K., Richer, S., 2008. Archéologie et paléoenvironnement dans les Alpes méridionales françaises: hauts massifs de l'Argentiérois, du Champsaur et de l'Ubaye, Hautes-Alpes et Alpes-de-Haute-Provence. Néolithique final début de l'Antiquité 6, 253-272.

Mocci, F., Segard, M., Walsh, K., Golosetti, R., Dumas, V., Cenzon-Salvayre, C. Talon, B., 2010. Données récentes sur l'occupation humaine dans les Alpes méridionales durant l'Antiquité. Archéologie de la montagne européenne $301-317$

Moreno, A., López-Merino, L., Leira, M., Marco-Barba, J., González-Sampériz, P., Valero-Garcés, B.L., López-Sáez, J.A., Santos, L., Mata, P., Ito, E., 2011. Revealing the last 13,500 years of environmental history from the multiproxy record of a mountain lake (Lago Enol, northern Iberian Peninsula). J. Paleolimnol. 46, 
$327-349$.

Naeher, S., Gilli, A., North, R.P., Hamann, Y., Schubert, C.J., 2013. Tracing bottom water oxygenation with sedimentary $\mathrm{Mn} / \mathrm{Fe}$ ratios in Lake Zurich, Switzerland. Chem. Geol. 352, 125-133.

Ortu, E., 2002. Reconstruction sur base pollinique de la dynamique de la végétation tardiglaciaire et holocène dans les Alpes Maritimes Italiennes. PhD thesis. AixMarseille Université III (France). 179pp.

Pansu, J., Giguet-Covex, C., Ficetola, G.F., Gielly, L., Boyer, F., Zinger, L., Arnaud, F. Poulenard, J., Taberlet, P., Choler, P., 2015. Reconstructing long-term human impacts on plant communities: an ecological approach based on lake sediment DNA. Mol. Ecol. 24, 1485-1498.

Parker, B.R., Vinebrooke, R.D., Schindler, D.W., 2008. Recent climate extremes alter alpine lake ecosystems. Proc. Natl. Acad. Sci. Unit. States Am. 105, 12927-12931.

Pérez-Sanz, A., González-Sampériz, P., Moreno, A., Valero-Garcés, B., Gil-Romera, G. Rieradevall, M., Tarrats, P., Lasheras-Álvarez, L., Morellón, M., Belmonte, A., Sancho, C., Sevilla-Callejo, M., Navas, A., 2013. Holocene climate variability, vegetation dynamics and fire regime in the central Pyrenees: the Basa de la Mora sequence (NE Spain). Quat. Sci. Rev. 73, 149-169.

Perga, M.-E., Frossard, V., Jenny, J.-P., Alric, B., et al., 2015. High-resolution paleolimnology opens new management perspectives for lakes adaptation to climate warming. Front. Ecol. Evol. 3, 72.

Petersen, J., Wilhelm, B., Revel, M., Rolland, Y., Crouzet, C., Arnaud, F., Brisset, E. Chaumillon, E, Magand, O, 2014. Sediments of lake Vens (SW european Alps, France) record large-magnitude earthquake events. J. Paleolimnol. 51, 343-355.

Petit-Maire, N., Riser, J., Blanc-Vernet, L., 1983. Sahara ou Sahel ? Quaternaire récent du bassin de Taoudenni (Mali). Laboratoire de géologie du quaternaire du Centre national de la recherche scientifique, $473 \mathrm{pp}$

Pini, R., Ravazzi, C., Raiteri, L., Guerreschi, A., Castellano, L., Comolli, R., 2017. From pristine forests to high-altitude pastures: an ecological approach to prehistoric human impact on vegetation and landscapes in the western Italian Alps. J. Ecol. $105,1580-1597$.

Ponel, P., Andrieu-Ponel, V., Parchoux, F., Juhasz, I., de Beaulieu, J.-L., 2001. Lateglacial and Holocene high-altitude environmental changes in Vallée des Merveilles (Alpes-Maritimes, France): insect evidence. J. Quat. Sci. 16, 795-812.

Ponel, P., Court-Picon, M., Badura, M., Guiter, F., Beaulieu, J.-L., de, Andrieu-Ponel, V., Djamali, M., Leydet, M., Gandouin, E., Buttler, A., 2011. Holocene history of Lac des Lauzons (2180 $\mathrm{m}$ a.s.l.), reconstructed from multiproxy analyses of Coleoptera, plant macroremains and pollen (Hautes-Alpes, France). Holocene 21, 565-582.

Pross, J., Kotthoff, U., Müller, U.C., Peyron, O., Dormoy, I., Schmiedl, G., Kalaitzidis, S. Smith, A.M., 2009. Massive perturbation in terrestrial ecosystems of the Eastern Mediterranean region associated with the $8.2 \mathrm{kyr}$ B.P. climatic event. Geology 37, 887-890.

Quesada, B., Sylvestre, F., Vimeux, F., Black, J., et al., 2015. Impact of Bolivian paleolake evaporation on the $\delta 18 \mathrm{O}$ of the Andean glaciers during the last deglaciation (18.5-11.7 ka): diatom-inferred $\delta 18 \mathrm{O}$ values and hydro-isotopic modeling. Quat. Sci. Rev. 120, 93-106.

Reille, M., 1999. Pollen et spores d'Europe et d'Afrique du nord. 2ème édition. Laboratoire de Botanique Historique et Palynologie, Marseille, 327 pp.

Reimer, P., et al., 2013. IntCal13 and Marine13 radiocarbon age calibration curves $0-50,000$ Years cal BP. Radiocarbon 55, 1869-1887.

Rey, F., Schwörer, C., Gobet, E., Colombaroli, D., Leeuwen, J.F., van, Schleiss, S., Tinner, W., 2013. Climatic and human impacts on mountain vegetation at Lauenensee (Bernese Alps, Switzerland) during the last 14,000 years. Holocene 23, 1415-1427.

Richer, S., 2009. From Pollen to People: the Interaction between People and Their Environment in the Mid- to High- Altitudes of the Southern French Alps. PhD thesis. York University, UK, 356pp.

Richter, S., Kipfer, T., Wohlgemuth, T., Guerrero, C.C., Ghazoul, J., Moser, B., 2012. Phenotypic plasticity facilitates resistance to climate change in a highly variable environment. Oecologia 169, 269-279.

Roberts, N., Eastwood, W.J., Kuzucuoğlu, C., Fiorentino, G., Caracuta, V., 2011. Climatic, vegetation and cultural change in the eastern Mediterranean during the mid-Holocene environmental transition. Holocene 21, 147-162.

Round, F.E., Crawford, R.M., Mann, D.G., 1990. The Diatoms: Biology \& Morphology of the Genera. Cambridge University Press, $768 \mathrm{pp}$

Rühland, K., Paterson, A.M., Smol, J.P., 2008. Hemispheric-scale patterns of climaterelated shifts in planktonic diatoms from North American and European lakes.
Global Change Biol. 14, 2740-2754.

Schillereff, D.N., Chiverrell, R.C., Macdonald, N., Hooke, J.M., 2014. Flood stratigraphies in lake sediments: a review. Earth Sci. Rev. 135, 17-37.

Schmid, A.-M.M., Crawford, R.M., 2001. Ellerbeckia arenaria (Bacillariophyceae): formation of auxospores and initial cells. Eur. J. Phycol. 36, 307-320.

Schmidt, R., Kamenik, C., Tessadri, R., Koinig, K.A., 2006. Climatic changes from 12,000 to 4,000 Years ago in the Austrian central Alps tracked by sedimentological and biological proxies of a lake sediment core. J. Paleolimnol. 35, 491-505.

Schnurrenberger, D., Russell, J., Kelts, K., 2003. Classification of lacustrine sediments based on sedimentary components. J. Paleolimnol. 29, 141-154.

Schwörer, C., Kaltenrieder, P., Glur, L., Berlinger, M., Elbert, J., Frei, S., Gilli, A. Hafner, A., Anselmetti, F.S., Grosjean, M., Tinner, W., 2014. Holocene climate, fire and vegetation dynamics at the treeline in the Northwestern Swiss Alps. Veget Hist Archaeobot 23, 479-496.

Stone, J.R., Fritz, S.C., 2004. Three-dimensional modeling of lacustrine diatom habitat areas: improving paleolimnological interpretation of planktic: benthic ratios. Limnol. Oceanogr. 49 (5), 1540-1548.

Tinner, W., Conedera, M., Ammann, B., Lotter, A.F., 2005. Fire ecology north and south of the Alps since the last ice age. Holocene 15, 1214-1226.

Tóth, M., Buczkó, K., Specziár, A., Heiri, O., Braun, M., Hubay, K., Czakó, D., Magyari, E.K., 2017. Limnological Changes in South Carpathian Glacier-formed Lakes (Retezat Mountains, Romania) during the Late Glacial and the Holocene: a Synthesis. Quaternary International.

Vermeulen, S., Lepoint, G., Gobert, S., 2012. Processing samples of benthic marine diatoms from Mediterranean oligotrophic areas. J. Appl. Phycol. 24, 1253-1260.

Walker, M.J.C., Berkelhammer, M., Björck, S., Cwynar, L.C. Fisher, D.A., Long, A.J. Lowe, J.J., Newnham, R.M., Rasmussen, S.O., Weiss, H., 2012. Formal subdivision of the Holocene series/epoch: a discussion paper by a working group of INTIMATE (integration of ice-core, marine and terrestrial records) and the subcommission on quaternary stratigraphy (international commission on stratigraphy). J. Quat. Sci. 27, 649-659.

Walsh, K.J., Mocci, F., 2016. Driving forces and variability in the exploitation of a high-altitude landscape from the Neolithic to Medieval Periods in the southern French Alps. In: Collis, J.R., Nicolis, F., Pearce, M. (Eds.), Summer Farms: Seasonal Exploitation of the Uplands from Prehistory to the Present, vol 16. J.R. Collis Publications, Sheffield, pp. 183-201.

Walsh, K., Mocci, F., Palet-Martínez, J., 2007. Nine thousand years of human/landscape dynamics in a high altitude zone in the southern French Alps (Parc National des Ecrins, Hautes-Alpes). Preistoria Alp. 42, 9-22.

Walsh, K., Court-Picon, M. de Beaulieu, J-L, Guiter, F, Mocci, F, Richer, S., Sinet, R., Talon, B., Tzortzis, S., 2014. A historical ecology of the Ecrins (southern French Alps): archaeology and palaeoecology of the mesolithic to the medieval period. Quat. Int. Environ. Hist. Eur. High Mt. 353, 52-73.

Weiss, H., 2015. In: Meller, H., Arz, H.W., Jung, R., Risch, R. (Eds.), Megadrought, collapse, and resilience in late 3rd millennium BC Mesopotamia, pp. 35-52, 2015.

Wilhelm, B., Arnaud, F., Sabatier, P., Crouzet, C., Brisset, E., Chaumillon, E., Disnar, J.R., Guiter, F., Malet, E., Reyss, J.-L., Tachikawa, K., Bard, E., Delannoy, J.-J., 2012. 1400 years of extreme precipitation patterns over the Mediterranean French Alps and possible forcing mechanisms. Quat. Res. 78, 1-12.

Wilhelm, B., Sabatier, P., Arnaud, F., 2015. Is a regional flood signal reproducible from lake sediments? Sedimentology 62, 1103-1117.

Winder, M., Reuter, J.E., Schladow, S.G., 2009. Lake warming favours small-sized planktonic diatom species. Proc. R. Soc. Lond. B Biol. Sci. 276, 427-435.

Wischnewski, J., Mischke, S., Wang, Y., Herzschuh, U., 2011. Reconstructing climate variability on the northeastern Tibetan Plateau since the last Lateglacial - a multi-proxy, dual-site approach comparing terrestrial and aquatic signals. Quat. Sci. Rev. 30, 82-97.

Wolfe, A.P., Van Gorp, A.C., Baron, J.S., 2003. Recent ecological and biogeochemical changes in alpine lakes of Rocky Mountain National Park (Colorado, USA): a response to anthropogenic nitrogen deposition. Geobiology 1, 153-168.

Wunsam, S., Schmidt, R., Klee, R., 1995. Cyclotella-taxa (Bacillariophyceae) in lakes of the Alpine region and their relationship to environmental variables. Aquat. Sci. 57, 360-386.

Yu, G., Harrison, S.P., 1995. Holocene changes in atmospheric circulation patterns as shown by lake status changes in northern Europe. Boreas 24, 260-268. 